\title{
Can Population Genetic Structure Be Predicted from Life-History Traits?
}

\author{
Jérôme Duminil, ${ }^{1, *}$ Silvia Fineschi, ${ }^{2, \dagger}$ Arndt Hampe, ${ }^{3, \uparrow}$ Pedro Jordano, ${ }^{3, \$}$ Daniela Salvini, ${ }^{4, \|}$ \\ Giovanni G. Vendramin, ${ }^{5, *}$ and Rémy J. Petit ${ }^{1, * *}$
}

1. Unité Mixte de Recherche Biodiversité Gènes et Ecosystèmes, Institut National de Recherches Agronomiques Cestas, France;

2. Istituto per la Protezione delle Piante, Consiglio Nazionale delle Ricerche, Sesto Fiorentino, Italy;

3. Integrative Ecology Group, Consejo Superior de Investigaciones Científicas, Estación Biológica de Doñana, Sevilla, Spain;

4. Danish Center for Forest, Landscape, and Planning, Royal

Veterinary and Agricultural University, Hørsholm, Denmark;

5. Istituto di Genetica Vegetale, Consiglio Nazionale delle Ricerche, Sesto Fiorentino, Italy

Submitted February 2, 2006; Accepted November 30, 2006;

Electronically published March 12, 2007

Online enhancements: appendixes.

AвSTRACt: Population genetic structure is a key parameter in evolutionary biology. Earlier comparative studies have shown that genetic structure depends on species ecological attributes and lifehistory traits, but species phylogenetic relatedness had not been accounted for. Here we reevaluate the relationships between genetic structure and species traits in seed plants. Each species is characterized by a set of life-history and ecological features as well as by its geographic range size, its heterozygote deficit, and its genetic structure at nuclear and organelle markers to distinguish between pollenand seed-mediated gene flow. We use both a conventional regression approach and a method that controls for phylogenetic relationships. Once phylogenetic conservatism and covariation among traits are taken into account, genetic structure is shown to be related with only a few synthetic traits, such as mating system for nuclear markers and seed dispersal mode or geographic range size for organelle mark-

\footnotetext{
* E-mail: duminil@pierroton.inra.fr.

† E-mail: s.fineschi@ipp.cnr.it.

* E-mail: arndt@ebd.csic.es.

s E-mail: jordano@ebd.csic.es.

" E-mail: dsa@kvl.dk.

\# E-mail: giovanni.vendramin@igv.cnr.it.

** Corresponding author; e-mail: petit@pierroton.inra.fr.
}

Am. Nat. 2007. Vol. 169, pp. 662-672. () 2007 by The University of Chicago. 0003-0147/2007/16905-41603\$15.00. All rights reserved. ers. Along with other studies on invasiveness or rarity, our work illustrates the fact that predicting the fate of species across a broad taxonomic assemblage on the basis of simple traits is rarely possible, a testimony of the highly contingent nature of evolution.

Keywords: comparative method, chloroplast markers, independent contrasts, nuclear markers, pollen dispersal, seed dispersal.

Investigations of population genetic structure are a prerequisite for the understanding of species evolution, because they help in assessing to what extent distinct populations have embarked on separate evolutionary trajectories or remain linked by gene flow; whereas weak genetic structure points to species cohesion, the contrary can imply incipient speciation. As a consequence, genetic structure has been investigated and its causes discussed in thousands of studies involving virtually any type of organism. Both population history and species-specific characteristics have been considered to shape genetic structure. For instance, it is now well documented that past climatic variations have strongly affected the current geographic distribution of genetic lineages (Hewitt 2000; Petit et al. 2003, 2005a). Genetic structure should also be influenced by life-history traits (LHT), species distribution, and other ecological features of species that are more or less directly related to gene dispersal (hereafter collectively referred to as LHT). However, evaluating the relative dispersal ability of distantly related species on the basis of the assessment of specific traits is not straightforward. For instance, an increase in seed mass is unlikely to have the same consequence on seed dispersal in orchids (whose tiny seeds are dispersed by wind) and in oaks (whose acorns are cached by animals).

It is therefore surprising that previous cross-species analyses of the plant population genetics literature have found such strong associations between measures of the organization of genetic diversity (such as $G_{\mathrm{ST}}$, which measures the proportion of total genetic variation that resides among populations) and various characteristics of the species. In particular, mating system, life form, and, to a lesser 
extent, mode of pollen and seed dispersal and geographic range have been considered to be predictors of $G_{\mathrm{ST}}$ in surveys of the isozyme literature (Loveless and Hamrick 1984; Hamrick and Godt 1989; Hamrick et al. 1992; Hamrick and Godt 1996), and similar conclusions have been reached in recent reviews based on nuclear DNA markers (Nybom and Bartish 2000; Nybom 2004). These reviews and meta-analyses have generated much interest and continue to motivate theoretical or empirical research in the field. For instance, Austerlitz et al. (2000) justify their theoretical work on the effects of colonization process in trees versus annual plants by the empirical evidence of a lower $G_{\mathrm{ST}}$ in trees than in herbs. Similarly, Pacheco and Simonetti $(2000$, p. 1767) introduce their study of a mimosoid tree deprived of its seed disperser by recalling that "species that are biotically dispersed generally show less population differentiation than those abiotically dispersed." More recently, Moyle (2006, p. 1068) recalled that "broad-scale comparisons among endemic versus widespread ... species have shown contrasting and distinctive patterns of genetic variation among populations in these groups."

The implicit assumption behind these widely accepted tenets is that an evolutionary correlation exists between ecological traits and $G_{\mathrm{ST}}$ across species, resulting in similar $G_{S T}$ values for species sharing similar LHT. However, there are two potential pitfalls when attempting to interpret the relationships between $G_{\mathrm{ST}}$ and LHT using cross-species analyses: nonindependence of the taxa and nonindependence of the LHT themselves.

First, most published studies have treated species as independent data points without attempting to account for phylogenetic nonindependence (but see Gitzendanner and Soltis 2000 and Aguinagalde et al. 2005 for plants or Bohonak 1999 for animals). Such direct cross-species comparisons have been dubbed TIPs because they compare the extant species at the tips of the phylogeny (Martins and Garland 1991). However, LHT often present a strong phylogenetic inertia, that is, a tendency to resist evolutionary change despite environmental changes (Morales 2000). Biologically, this means that patterns of shared ancestry, not adaptation to the changing environment, are driving variation in LHT across species. Statistically, this results in nonindependence of data in cross-species analyses and hence in an increase in the Type I error rate (the risk of incorrectly rejecting the null hypothesis of no relationship among traits; Garland et al. 2005). An important aspect of this problem, which is not yet widely appreciated, is that this lack of independence between species cannot be compensated for by increasing sample size (Ackerly 2000). This is because the critical values for significance testing decline rapidly with increasing sample sizes, whereas the number of truly independent comparisons increases only slowly, so more of the outcomes are judged significant when standard statistical criteria based on the usual assumption of independence are used. Fortunately, different methods have been developed to deal with this problem, and they are increasingly used in comparative studies (e.g., Felsenstein 1985; Martins and Garland 1991; Paradis and Claude 2002; Housworth et al. 2004).

Second, LHT are often correlated with each other, thereby confounding the relationships with $G_{\mathrm{ST}}$. Examples of associations between traits that have been detected in cross-species comparisons include those between breeding system (i.e., gender variation), pollen dispersal, and growth form of the species (Renner and Ricklefs 1995); between animal-mediated dispersal and fruit diameter (Jordano 1995); between seed mass, dispersal mode, and growth form (Westoby et al. 1996); between breeding system, plant distribution, growth form, and pollen dispersal (Vamosi et al. 2003); between seed mass and growth form (Moles et al. 2005); between longevity and mating system (Barrett et al. 1996); and between mating system and pollen dispersal (Vogler and Kalisz 2001). Hence, we need to account for phylogenetic effects and to cope for trait interactions when assessing the evolutionary relationships between $G_{\mathrm{ST}}$ and LHT.

Previous comparative studies could not take advantage of the complementary information provided by different types of DNA markers, because the bulk of the literature on organelle DNA variation in plants is very recent (Petit et al. 2005b; Petit and Vendramin 2006). Plants have three distinct intracellular genomes characterized by a contrasted mode of inheritance (Petit et al. 2005b). In seed plants, the rule is that organelle DNA is inherited maternally (except chloroplast DNA in conifers, which is predominantly paternally inherited). In contrast, the nuclear genome is biparentally inherited. Hence, whereas nuclear markers are transmitted via pollen and seeds, maternally inherited markers are transmitted via seeds only. Accordingly, LHT could differentially affect genetic structure at biparentally inherited markers (hereafter $G_{\mathrm{STb}}$ ) and at maternally inherited markers (hereafter $G_{\mathrm{STm}}$ ), and the inclusion of both fixation indexes $\left(G_{\mathrm{STb}}\right.$ and $\left.G_{\mathrm{STm}}\right)$ should help distinguish between the consequences of pollen- and seedmediated gene flow on genetic structure.

Here we test the influence of a set of LHT on $G_{\mathrm{STb}}$ and $G_{\text {STm }}$ in seed plants. Traits that have been reported to directly or indirectly influence gene flow through pollen or seeds were investigated (growth form, plant size, perenniality, seed dispersal mode, seed mass, reproduction type, and geographic range for both $G_{\mathrm{STb}}$ and $G_{\mathrm{STm}}$; pollination mode, mating system, and breeding system for $G_{\mathrm{STb}}$ only). We also consider the relationship between $G_{\mathrm{STb}}$ and the within-population inbreeding coefficient $F_{\mathrm{IS}}$ (Wright 1951). We use both TIPs and Felsenstein's method based 
on phylogenetically independent contrasts (PICs) to investigate whether previous studies (based on TIPs) have resulted in robust inferences. We also examine whether the identified relationships persist when other traits are used as covariates in the analyses.

\section{Material and Methods}

\section{List of Studied Taxa}

Of the 164 studies of the distribution of genetic diversity within and among plant populations based on maternally inherited organelle DNA markers compiled previously (Petit et al. 2005b), we discarded those dealing with aquatic species (insufficiently represented) and those studies that had first pooled individuals for screening variation, because this seemed to result in some bias in the estimate of $G_{\mathrm{STm}}$ (Petit et al. 2005b). Altogether 141 species were retained. When a species had been studied with both chloroplast and mitochondrial markers, the mean between the two $G_{\mathrm{STm}}$ estimates was used if both genomes were similarly maternally inherited (there were eight species in that case), because $G_{\text {STm }}$ estimated with markers from either genome closely co-vary (Petit et al. 2005b). The molecular techniques employed in the different genetic diversity studies were as described by Petit et al. (2005b). The set of species covers all five continents and all climatic zones, although Northern Hemisphere species are overrepresented. The same database was used to investigate the genetic structure at nuclear markers $\left(G_{\mathrm{STb}}\right)$. A total of 112 species were available for this purpose, including 103 common with the previous set of 141 species (150 distinct species in total).

\section{List of Plant Species Characters}

For each species, a set of LHT was compiled (see app. A in the online edition of the American Naturalist). The information was obtained from various sources, including the original articles used to compile genetic structure (listed in Petit et al. 2005b), standard works such as floras and peer-reviewed publications identified with Isi Web of Science, and direct contact with the authors of the original articles.

We considered a widely used list of plant features in order to maximize the comparability of our results with former work. We merged some of the categories used by previous authors in order to obtain a sufficient sample size. Categories were as follows.

Taxonomic status of the species. Each species has been classified at five taxonomic levels (plant group, subclass, order, family, genus) according to the classification used on the NCBI taxonomy browser Web site (http:// www.ncbi.nlm.nih.gov/Taxonomy/). The first level (termed plant group) defines whether the species is a gymnosperm, a eumagnoliid, or a eudicot. Then each species is characterized by its subclass, order, family, and genus. Six subclasses were represented (Asteridae, Caryophyllidae, Coniferopsida, Liliidae, Magnoliidae, and Rosidae), as well as 25 orders, 45 families, and 86 genera (see app. A).

Growth form. Herbaceous: forb + graminoid, vine, shrub, tree. A shrub was defined as a woody plant, usually smaller than a tree, that produces several stems rather than a single trunk from the base. A tree was defined as a perennial plant that grows from the ground with a single, normally tall, woody, self-supporting trunk or stem and an elevated crown of branches and foliage. Because only two species (Hedera helix and Vitis vinifera) were vines in our data set, this category was not included in the analysis of relationships between $G_{\mathrm{ST}}$ and growth form.

Perenniality. Annual, biennial, short-lived perennial, long-lived perennial.

Seed dispersal. Wind, animal ingested, animal attached, animal cached, gravity. The corresponding botanical names are anemochorous, endozoochorous, epizoochorous, diszoochorous, and barochorous, respectively, but for the sake of clarity, we stick to the simpler terms in the text. Assignment to these categories was based either on particular anatomic features that hint at specific modes of dispersal or on published field observations.

Pollen dispersal. Anemophilous, zoophilous.

Mating system. Selfed, mixed, outcrossed.

Heterozygote deficit $\left(\mathrm{F}_{I S}\right)$. Data were taken directly from studies on nuclear diversity based on codominant genetic markers. Sometimes other publications than the article that provided the $G_{\mathrm{ST}}$ estimate had to be consulted.

Breeding system. Hermaphrodite/monoecious, gynodioecious, dioecious. The distribution of sexes is considered at the level of the plant, not at the level of the flower. Hence, hermaphrodite plants (male and female function both present in the same flowers) were pooled with monoecious plants (male and female function in separate flowers of the same individual).

Reproduction. Both sexual and vegetative, sexual only.

Geographic range. Endemic, narrow, regional, and widespread. Following previous surveys, we used a threshold of $50,000 \mathrm{~km}^{2}$ to define endemic species. A species' geographic range size was considered narrow if it occupies $<25 \%$ of its continent, regional if it is distributed over $>25 \%$ but $<50 \%$, and widespread if it is distributed over $>50 \%$.

Seed mass and plant size. We used estimates of dry seed mass ( $\mathrm{mg} \mathrm{seed}^{-1}$ ) and plant height $(\mathrm{m})$.

\section{Data Analysis}

Transformation of the Variables. To improve normality, $G_{\mathrm{ST}}$ and $F_{\mathrm{IS}}$ estimates were arcsine-square root transformed, 
and seed mass and plant size were log transformed. The remaining variables are either binary (pollination mode, reproductive type) or multiple-state categorical variables. Among the latter, all but one (mode of seed dispersal) could be ranked to yield semiquantitative variables. The following notations were used: for growth form, herbaceous $=1$, shrub $=2$, tree $=3$; for perenniality, annual $=1$, biennial $=2$, short-lived perennial $=3$, long-lived perennial $=4$; for pollination mode, anemophilous $=0$, zoophilous $=1$; for reproductive type, sexual and vegetative $=0$, sexual only $=1$; for mating system, selfed $=1$, mixed $=2$, outcrossed $=3$; for breeding system, monoecious $=1$, gynodioecious $=2$, dioecious $=3$; for geographic range, endemic $=1$, narrow $=2$, regional $=3$, widespread $=4$. Each of the five seed dispersal categories was transformed into a 0,1 dummy variable because we could not think of an objective way to rank them to yield a semiquantitative variable.

Taxonomic Effects. For the nested ANOVA, we specified the taxonomic levels (plant group, subclass, order, family, genus) as nested random effects within each higher level. We estimated the variance components for the sequential Type I sum of squares because the results were consistent with those obtained with Type III sum of squares for our unbalanced design (Bell 1989). A PROC GLM procedure was used to fit the nested ANOVA model with SAS software (ver. 9.1 for Windows 2004; SAS Institute, Cary, NC). Computations of Abouheif's (1999) test for serial dependence were carried out using R (ver. 2.0.1; Ihaka and Gentleman 1996) with the ade4 package (available at http:// www.r-project.org/). Phylogenetic signal was measured for each continuous or ranked variable: seed mass, plant size, perenniality, growth form, breeding system, range size, pollen dispersal, reproduction type, $F_{\mathrm{IS}}, G_{\mathrm{STm}}$, and $G_{\mathrm{STb}}$.

Conventional Comparisons (TIPs). Simple linear regressions and one-way ANOVAs with the GLM procedure were performed with SYSTAT, version 10.2.05 (SYSTAT 2002). To facilitate comparisons between TIPs and PICs approaches, the conventional (TIPs) approach was based on regressions rather than on ANOVAs. However, we also performed ANOVAs, and the conclusions were identical (results not shown).

Phylogenetically Independent Contrasts (PICs). The reference plant phylogeny used is that of Soltis et al. (2000). Because not all studied species were present in this phylogeny, missing species were grafted according to information available in other phylogenetic studies (Rieseberg 1991; Wang and Szmidt 1993; Schilling and Linder 1998; Hedren 2001; Hedren et al. 2001; Soltis et al. 2001; A. Wolfe, personal communication). Either intragenus phy- logenetic relationships were reconstructed following Arduino et al. (1996), Liston et al. (1999), Manos et al. (1999), and http://www.fmnh.helsinki.fi/users/haaramo/ Plantae/Coniferophyta/Pinaceae/Abies.htm, or they were left as soft polytomies when the infragenus relationships could not be resolved with the available information (in the case of Betula sp., Helianthus sp., Sorbus sp., Senecio sp., Packera sp.). The phylogenetic supertree used for the analyses is presented in appendix B in the online edition of the American Naturalist. All branch lengths were assigned a value of 1. With Felsenstein's (1985) method of independent contrasts, one assumption is that characters evolve following a Brownian motion model and that branch lengths are expressed in units of expected amount of character change. However, this method generally performs well when information on branch lengths is missing (Martins and Garland 1991). Considering all branches equal signifies that the characters investigated are assumed to follow a model of a punctuational evolution, with changes taking place only at speciation events (Martins and Garland 1991). A standard procedure to ascertain that the punctuational model of evolution assumptions leads to adequately standardized independent contrasts was proposed by Garland et al. (1992). The verification procedure consists of plotting the absolute value of each standardized independent contrast as a function of its standard deviation. Any significant trend in the plot indicates that the contrasts are not adequately standardized and that phenotypic data or branch lengths have to be transformed. All regressions had a slope close to 0 (data not shown), indicating that the assumption of equal branch lengths is not biasing the results (app. C in the online edition of the American Naturalist).

Independent contrasts (Felsenstein 1985) were estimated with CAIC, version 2.6 (Purvis and Rambaud 1995). When dealing with categorical data, the Brunch option was used (Purvis and Rambaud 1995).

Partial Regressions. To check whether observed relationships between given LHT traits and $G_{\mathrm{STb}}$ could be the result of correlations between predictor LHT variables, partial regressions were performed on the independent contrasts using SYSTAT, version 10.2.05 (SYSTAT 2002). Regressions were forced through the origin (Felsenstein 1985).

\section{Results \\ Phylogenetic Signal}

A first logical step in comparative approaches is to test whether there is a phylogenetic signal in the data (Freckleton et al. 2002). Nested ANOVAs (Bell 1989) and tests for serial dependence (Abouheif 1999) were used for this 
Table 1: Nested ANOVA and variance component estimations for population genetic structure indexes based on biparentally $\left(G_{\mathrm{STb}}\right)$ and maternally inherited markers $\left(G_{\mathrm{STm}}\right)$

\begin{tabular}{|c|c|c|c|c|c|c|c|c|c|c|}
\hline \multirow[b]{2}{*}{ Level } & \multicolumn{5}{|c|}{$G_{\mathrm{STb}}$} & \multicolumn{5}{|c|}{$G_{\text {STm }}$} \\
\hline & df & SS & $F$ & $P$ & $\begin{array}{c}\text { Variance } \\
\text { component } \\
(\%)\end{array}$ & $\mathrm{df}$ & SS & $F$ & $P$ & $\begin{array}{l}\text { Variance } \\
\text { component } \\
(\%)\end{array}$ \\
\hline Plant group & 2 & .194 & 2.76 & .079 & 2.48 & 2 & .314 & 3.25 & .046 & 2.30 \\
\hline Subclass & 3 & .297 & 2.82 & .054 & 3.80 & 3 & .061 & .42 & .737 & .45 \\
\hline Order & 14 & 1.881 & 3.83 & $<.001$ & 24.06 & 19 & 4.267 & 4.65 & $<.001$ & 31.30 \\
\hline Family & 11 & 1.403 & 3.63 & .002 & 17.94 & 19 & 2.273 & 2.48 & .005 & 16.68 \\
\hline Genus & 26 & 2.921 & 3.20 & .001 & 37.35 & 40 & 4.061 & 2.1 & .005 & 29.79 \\
\hline Error term & 32 & 1.124 & $\ldots$ & $\ldots$ & 14.37 & 55 & 2.655 & $\ldots$ & $\ldots$ & 19.48 \\
\hline
\end{tabular}

Note: SS $=$ sum of squares. Significant $P$ values in bold.

purpose. Nested ANOVAs were performed to detect the proportion of variance present at each taxonomic level for the variables $G_{\mathrm{STb}}$ and $G_{\mathrm{STm}}$. They demonstrate that taxonomically related species partition genetic diversity in a similar way across populations: phylogenetic effects up to order level explain $79 \%\left(G_{\mathrm{STb}}\right)$ and $77 \%\left(G_{\mathrm{STm}}\right)$ of the total variance of these variables (table 1). Similarly, many of the predictor LHT variables present a significant phylogenetic signal according to Abouheif's (1999) test for serial dependence, with the exception of breeding system, mating system, and reproductive type (fig. 1).

\section{Relationships between $\mathrm{LHT}$ and $\mathrm{G}_{S T b}$}

Both conventional regressions (TIPs) and regressions based on PICs were carried out with each data set. The $G_{\text {STb }}$ presents multiple dependences on LHT when using TIPs analysis. In particular, plant growth form, plant size, perenniality, seed dispersal mode, seed mass, pollination mode, mating system, and $F_{\mathrm{IS}}$ are all related to $G_{\mathrm{STb}}$ (table 2; app. D in the online edition of the American Naturalist). However, several of these relationships disappear when using PICs. Only four remain: species that are perennial, dioecious, or outcrossed present lower $G_{\mathrm{STb}}$, as do species characterized by a low heterozygote deficit $\left(F_{\mathrm{IS}}\right.$; table 3 ; app. E in the online edition of the American Naturalist).

\section{Interactions between Predictor Variables}

To check whether the observed relationships between specific traits and $G_{\mathrm{STb}}$ could be affected by interactions between predictor variables (i.e., result from indirect effects of another predictor variable), a correlation analysis based on PICs was performed. Mating system is correlated with both sexual type and perenniality, with outcrossing plants being more often perennial and dioecious, whereas lower $F_{\text {IS }}$ values are typically observed in dioecious, outcrossed perennial species (fig. 2). To take these interactions into account in subsequent analyses, partial regressions based on PICs were used. The fixation index $F_{\mathrm{IS}}$ appears to be the best predictor variable of $G_{\mathrm{STb}}$, because $G_{\mathrm{STb}}$ still depends significantly on $F_{\mathrm{IS}}$ when perenniality, sexual type, or mating system are controlled for, whereas the opposite does not hold (table 4).

\section{Relationships between LHT and $\mathrm{G}_{S T m}$}

According to TIPs analyses, $G_{\text {STm }}$ depends on seed dispersal mode, reproduction type, and seed mass (table 2). Some of these relationships disappear when tested on PICs (table 3). One seed dispersal mode (gravity) and reproduction type remain significant, whereas geographic range size becomes significant in PICs analyses. Specifically, (i) species with gravity-dispersed seeds present larger $G_{\mathrm{STm}}$ values compared with species with other dispersal modes, (ii) species capable of vegetative reproduction have lower $G_{\mathrm{STm}}$

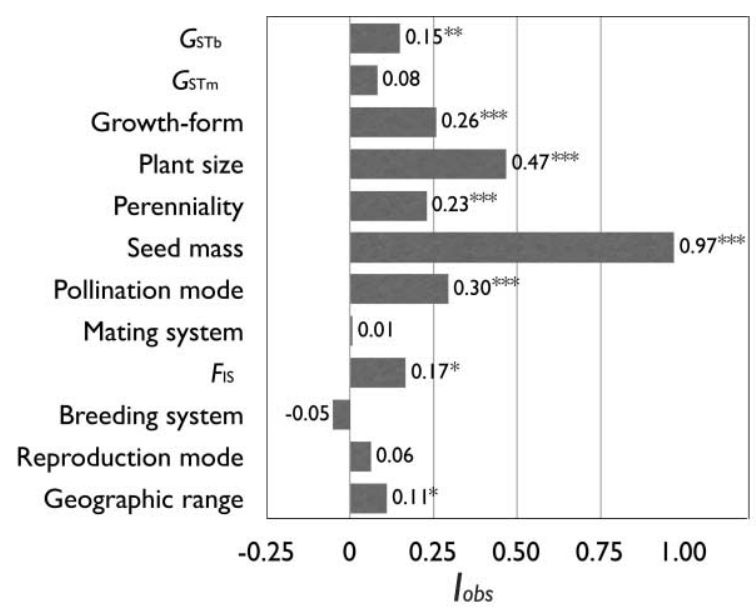

Figure 1: Estimation of phylogenetic signal for $G_{\mathrm{ST}}$ values and life-history traits according to Abouheif's (1999) method. Asterisks indicate the significance of the signal (one asterisk, .05 >P>.01; two asterisks, .01> $P>.001$; three asterisks, $P<.001)$. 
Table 2: Conventional regressions (TIPs) between $G_{\mathrm{STb}}$ or $G_{\mathrm{STm}}$ and independent life-history trait variables

\begin{tabular}{|c|c|c|c|c|c|c|c|c|}
\hline \multirow[b]{2}{*}{ Variable } & \multicolumn{4}{|c|}{$G_{\mathrm{STb}}$} & \multicolumn{4}{|c|}{$G_{\mathrm{STm}}$} \\
\hline & $N$ & Sign & $R^{2}$ & $P$ & $N$ & Sign & $R^{2}$ & $P$ \\
\hline Growth form & 115 & - & .15 & $<.001$ & 139 & + & .01 & .258 \\
\hline Plant size & 110 & - & .14 & $<.001$ & 132 & + & .01 & .207 \\
\hline Perenniality & 116 & - & .10 & $<.001$ & 141 & + & .01 & .203 \\
\hline \multicolumn{9}{|l|}{ Seed dispersal mode: } \\
\hline Wind & 109 & & .00 & .808 & 134 & & .00 & .712 \\
\hline Gravity & 109 & - & .02 & .114 & 134 & - & .01 & .181 \\
\hline Animal attached & 109 & - & .02 & .133 & 134 & + & .01 & .264 \\
\hline Animal ingested & 109 & & .00 & .658 & 134 & + & .04 & .029 \\
\hline Animal cached & 109 & + & .08 & .003 & 134 & - & .04 & .015 \\
\hline Seed mass & 112 & - & .04 & .030 & 136 & + & .06 & .005 \\
\hline Pollination mode & 108 & + & .13 & $<.001$ & $\ldots$ & & $\ldots$ & $\ldots$ \\
\hline Mating system & 112 & - & .16 & $<.001$ & $\ldots$ & & $\ldots$ & ... \\
\hline$F_{\mathrm{IS}}$ & 69 & + & .31 & $<.001$ & $\ldots$ & & $\ldots$ & $\ldots$ \\
\hline Breeding system & 116 & & .00 & .948 & 141 & & .00 & .567 \\
\hline Reproduction type & 103 & & .00 & .684 & 102 & - & .15 & $<.001$ \\
\hline Geographic range & 116 & & .00 & .669 & 140 & - & .02 & .074 \\
\hline
\end{tabular}

Note: $N$ indicates number of species (number of TIPs). The sign refers to the slope of the regression. Ellipses indicate relations that were not tested. Significant $P$ values in bold.

values than species with pure sexual reproduction (marginally; cf. the small $R^{2}$ ), and (iii) species with large range size tend to have low $G_{\mathrm{STm}}$ values.

\section{Discussion}

Related species tend to partition genetic diversity in similar ways within and among populations: nested ANOVAs and, to a lesser extent, tests for serial dependence indicate that much of the variation in $G_{\mathrm{ST}}$ at both nuclear and organelle markers is accounted for by the phylogenetic (or taxonomic) affinity of the species. Earlier studies had already demonstrated that $G_{\mathrm{STb}}$ tends to be similar in species belonging to the same family (e.g., Hamrick and Godt 1996), but this effect had not been further tested and quantified. Taxonomic affinity and phylogenetic relationships are not completely equivalent, which might explain some differences observed between nested ANOVAs and tests of serial dependence. Because closely related species tend to have similar ecological attributes and traits, it is a priori not surprising that they partition genetic diversity similarly within and among populations.

Using the conventional TIP approach, we confirmed many of the relationships identified previously between LHT and $G_{\text {Сть }}$ (Hamrick and Godt 1989, 1996), even though our data set is more limited. However, the existence of a strong phylogenetic signal supports our contention that the dependency of $G_{\mathrm{ST}}$ on LHT cannot be inferred from simple conventional comparisons across species. Accordingly, the results based on PICs reveal far fewer sig- nificant relations than those based on TIPs. In addition, most of the remaining relationships vanish when we consider the interactions among different LHT: only the relation of mating system with nuclear genetic structure remains significant. Hence, our results suggest that previously identified relationships between genetic structure and LHT need to be reevaluated within an explicit evolutionary context.

\section{Mating System}

The mating system seems to represent the only factor that directly affects genetic structure at nuclear genes $\left(G_{\mathrm{STb}}\right)$ across most seed plants. According to Charlesworth (2003, p. 1052), "[The mating system is] probably among the factors with major effects on variability, clear enough to be discernible even in the presence of other factors." Our results fully support this view. Other factors such as perenniality or breeding system are also suitable predictors of $G_{\mathrm{ST}}$, but direct causal relationships seem unlikely because the effects of these factors are no longer significant when controlling for variation in mating system. We attribute this to the fact that perenniality and breeding system are strongly correlated with the mating system. For instance, all dioecious species are necessarily allogamous, and no predominantly selfing tree species is known (Barrett 1998). 
Table 3: Phylogenetic regressions between $G_{\mathrm{STb}}$ or $G_{\mathrm{STm}}$ and independent lifehistory trait variables

\begin{tabular}{|c|c|c|c|c|c|c|c|c|}
\hline \multirow[b]{2}{*}{ Variable } & \multicolumn{4}{|c|}{$G_{\mathrm{STb}}$} & \multicolumn{4}{|c|}{$G_{\text {STm }}$} \\
\hline & $N$ & Sign & $R^{2}$ & $P$ & $N$ & Sign & $R^{2}$ & $P$ \\
\hline Growth form & 89 & - & .02 & .196 & 109 & - & .01 & .328 \\
\hline Plant size & 85 & - & .02 & .276 & 103 & - & .01 & .520 \\
\hline Perenniality & 90 & - & .05 & .031 & 111 & - & .01 & .353 \\
\hline \multicolumn{9}{|l|}{ Seed dispersal mode: } \\
\hline Wind & 19 & - & .04 & .207 & 23 & + & .00 & .773 \\
\hline Gravity & 9 & + & .06 & .482 & 13 & - & .41 & .013 \\
\hline Animal attached & 6 & + & .05 & .320 & 7 & & .00 & .986 \\
\hline Animal ingested & 13 & - & .03 & .533 & 16 & + & .20 & .070 \\
\hline Animal cached & 3 & + & .61 & .221 & 4 & + & .03 & .768 \\
\hline Seed mass & 87 & - & .00 & .303 & 106 & - & .00 & .520 \\
\hline Pollination mode & 8 & + & .27 & .346 & $\ldots$ & $\ldots$ & $\ldots$ & $\ldots$ \\
\hline Mating system & 88 & - & .11 & .002 & $\ldots$ & $\ldots$ & $\ldots$ & $\ldots$ \\
\hline$F_{\mathrm{IS}}$ & 57 & + & .35 & $<.001$ & $\ldots$ & $\ldots$ & $\ldots$ & $\ldots$ \\
\hline Breeding system & 90 & - & .13 & $<.001$ & 111 & + & .02 & .177 \\
\hline Reproduction type & 12 & - & .22 & .404 & 14 & - & .03 & .035 \\
\hline Geographic range & 90 & - & .00 & .667 & 110 & - & .06 & .010 \\
\hline
\end{tabular}

Note: $N$ indicates phylogenetically independent contrasts. The sign refers to the slope of the regression. Ellipses indicate relations that were not tested. Significant $P$ values in bold.

\section{Heterozygote Deficit}

The $G_{\mathrm{STb}}$ showed a stronger relationship with $F_{\mathrm{IS}}$ than with mating system. At least two factors could account for this difference. First, according to Wright (1965), $F_{\text {IS }}$ provides an indirect but quantitative estimate of the outcrossing rate $t$, assuming that (1) the outcrossing rate $(t)$ has been constant for a sufficient number of generations, (2) the population is in inbreeding equilibrium, and (3) selfing is the major cause of departure from Hardy-Weinberg frequencies. Under these assumptions, we have $F_{\mathrm{IS}}=(1-$ $t) /(1+t)$. Hence, $F_{\text {Is }}$ could reflect mating system more accurately than the three categories used to classify mating system, possibly resulting in a stronger relation with $G_{\mathrm{STb}}$. Second, heterozygote deficit is affected not only by mating system but also by genetic substructure within population (Wahlund 1928). Such a substructure could be caused by reduced seed or pollen gene flow. As a consequence, $F_{\mathrm{IS}}$ provides information on both mating system and gene dispersal distances within populations. This could explain why it shows a stronger relationship with $G_{\mathrm{STb}}$ than does mating system itself.

\section{Seed Dispersal Mode}

In TIP analyses, we found that species whose seeds are cached by animals had significantly lower $G_{\text {STb }}$ than species with other dispersal modes. Earlier studies (all based on TIPs) have also identified differences in nuclear genetic structure as a function of seed dispersal categories (Hamrick et al. 1993; Hamrick and Godt 1989, 1996; Nybom
2004). However, Hamrick and Nason (1996) have warned that rates of pollen flow could obscure the effects of seed dispersal mechanisms on nuclear genetic structure. A recent survey has confirmed that postfertilization gene flow (by seeds) accounts for a very limited fraction of overall nuclear gene flow (Petit et al. 2005b). Hence, our finding that the relationship between modes of seed dispersal and $G_{\text {STb }}$ no longer holds when using PICs makes biological sense. Moreover, the lack of correspondence between $G_{\mathrm{STb}}$

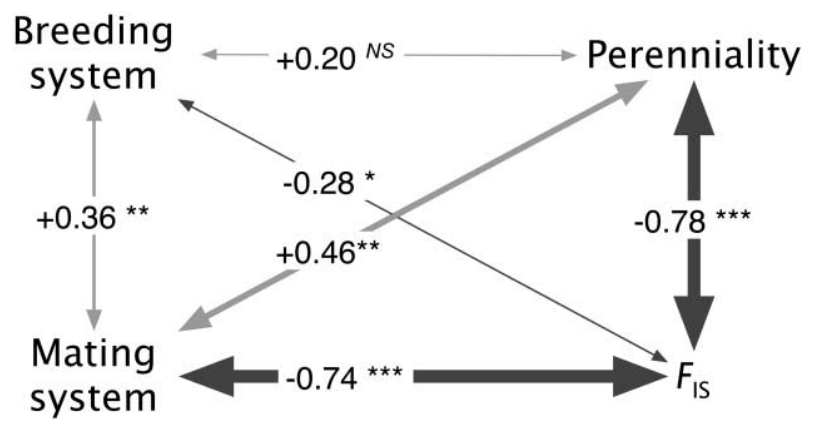

Figure 2: Correlations between life-history trait variables based on phylogenetically independent contrasts. Mating system is coded as a function of increasing allogamy (selfed, mixed, outcrossed) and breeding system as a function of increasing dicliny (hermaphroditic/monoecious, gynodioecious, dioecious). The values and significance of the Pearson correlations between contrasts when forced through the origin are indicated on arrows. Light gray lines, positive correlations; dark gray lines, negative correlations; arrow thickness is proportional to the $r$ value (one asterisk, $.05>P>.01$; two asterisks, $.01>P>.001$; three asterisks, $P<.001 ; N S$, not significant). 
Table 4: Partial regression coefficients based on phylogenetically independent contrasts for $G_{\mathrm{STb}}$ as a function of perenniality, breeding system, mating system, and heterozygote deficit $\left(F_{\mathrm{IS}}\right)$

\begin{tabular}{llccc}
\hline Relation between & & & & \\
$G_{\text {STb }}$ and & Controlled variable & $b_{\text {st }}$ & $R_{\text {part }}^{2}$ & $P$ \\
\hline Perenniality & Mating system & -.116 & .013 & .396 \\
Breeding system & Mating system & -.182 & .033 & .179 \\
$F_{\text {IS }}$ & Mating system & .292 & .085 & $\mathbf{. 0 2 9}$ \\
Perenniality & $F_{\text {IS }}$ & .106 & .011 & .435 \\
Breeding system & $F_{\text {IS }}$ & -.106 & .011 & .437 \\
Mating system & $F_{\text {IS }}$ & .029 & .001 & .830 \\
Mating system & Perenniality & -.169 & .029 & .214 \\
$F_{\text {IS }}$ & Perenniality & .289 & .083 & $\mathbf{. 0 3 1}$ \\
Mating system & Breeding system & -.273 & .075 & $\mathbf{. 0 4 2}$ \\
$F_{\text {IS }}$ & Breeding system & .447 & .200 & $\mathbf{. 0 0 1}$ \\
\hline
\end{tabular}

Note: The standardized partial regression coefficients $\left(b_{\mathrm{st}}\right)$, the partial $R^{2}$ $\left(R_{\text {part }}^{2}\right)$, and the associated $P$ values measure the effect of one variable after accounting for the effects of the other controlled variable; $N=55$ species for all regressions. Significant $P$ values in bold.

and $G_{\mathrm{STm}}$ across modes of seed dispersal indicates that inferences of seed movements based on biparentally inherited markers $\left(G_{\mathrm{STb}}\right)$ can be completely misleading.

In contrast, a straightforward relationship is expected between genetic structure at maternally inherited markers $\left(G_{\mathrm{STm}}\right)$ and those LHT that affect seed dispersal. In particular, species lacking specialized features for seed dispersal (gravity-dispersed seeds) should be characterized by high values of $G_{\text {STm }}$ in comparison with species characterized by more specialized biotic or abiotic seed dispersal modes. In agreement with this prediction, we found that species with gravity-dispersed seeds had significantly higher $G_{\mathrm{STm}}$ in PICs analyses. No significant relationships were identified between $G_{\mathrm{STm}}$ and the other modes of seed dispersal, although species with animal-ingested seeds had a rather low $G_{\mathrm{STm}}$. These results might be due to the difficulties in evaluating seed dispersal ability. First, many species have mixed seed dispersal strategies (e.g., Chambers and MacMahon 1994; Greene and Johnson 1995; Hampe 2004), reducing the relevance of the categories used. Second, the categories might be too broad. For instance, large differences in dispersal ability certainly exist among species with wind-dispersed seeds, depending on seed mass or on the actual anatomical adaptations (gliders, parachutes, helicopters, spinners, cottony seeds, etc.). Whereas tiny cottoneous, plumose, or dust seeds can be carried regularly over large distances, heavy samaras should be typically less effectively dispersed. Third, seed dispersal alone does not fully describe realized seedmediated gene flow, that is, the successful final establishment of a dispersed propagule; fruit/seed removal, seed delivery, seed predation, seed bank dynamics, germination, and seedling establishment might be equally important factors (Wang and Smith 2002).
Similarly, the lack of relationships between $G_{\text {STm }}$ and seed mass is not that surprising. An increase in seed mass is unlikely to have the same consequence for plants having very different seed dispersal modes. Whereas light seeds should favor dispersal for most anemochorous plants, this is not necessarily the case for species whose seeds are dispersed by animals (e.g., Bossema 1979). Moreover, larger seeds might favor seedling establishment success and competitive ability (especially in closed forest vegetation; Eriksson et al. 2000). Finally, the classical trade-off between seed mass and seed number in plants (Rees et al. 2001) could obscure the effect of seed mass on genetic structure, since seed number can affect the likelihood that a given seed is deposited in a suitable habitat.

Despite these potential difficulties, Aguinagalde et al. (2005) have described a positive relationship between $G_{\mathrm{STm}}$ and seed mass using the same analytical approach. However, their study was based on data from a more homogeneous sample (forest trees and shrubs) and region (Europe), increasing the comparability of the results. Altogether, the large number of factors involved helps us understand why generalizations of the effect of seed characteristics on population genetic structure at maternally inherited markers remain difficult, even if the relation is a priori much more direct than for nuclear markers.

\section{Geographical Range}

Although some studies have identified a relationship between geographic range and $G_{\mathrm{STb}}$ (Loveless and Hamrick 1984; Hamrick et al. 1992), most have not (Hamrick and Godt 1989; Nybom and Bartish 2000; Nybom 2004). Paired comparisons of $G_{\text {STъ }}$ in widespread and endemic species were not significant (Gitzendanner and Soltis 2000; Cole 2003). Here, $G_{\text {Ст }}$ was independent of range size regardless of the method used (TIPs and PICs analyses). However, results based on maternally inherited markers were different. Species with more restricted ranges (narrow and regional) are characterized by larger $G_{\mathrm{STm}}$ than widespread ones in PICs analyses, in line with the findings of Aguinagalde et al. (2005), who reported that European woody plant species with broad boreal-temperate distribution had smaller $G_{\mathrm{STm}}$ than more temperate species. The explanation that had been put forward to account for the relationship between $G_{S T}$ and geographic range size is that species with large ranges must necessarily have high colonization abilities (i.e., by seeds); otherwise, they would never have achieved such a broad distribution (e.g., Loveless and Hamrick 1984). Furthermore, the degree of range fragmentation often co-varies negatively with species range sizes (Higgins et al. 2003), since processes that move seeds may break down in disjunct populations. This could further contribute to increasing $G_{\mathrm{STm}}$ in narrowly distributed 
species. In any case, the fact that a relation with geographic range size was found for $G_{\mathrm{STm}}$ but not for $G_{\mathrm{STb}}$ makes sense, given the overwhelming importance of seed dispersal on range expansion. However, this relation does not hold for species with particularly small ranges (i.e., belonging to the endemic category), thus restricting the generality of this finding.

\section{Conclusions}

Few direct relations between genetic structure and LHT were supported by our analyses when explicitly testing for correlated evolution within a phylogenetic framework. The $G_{\text {STm }}$ is weakly related with geographic range size and with reproduction type. The only other factors that we found to be related with genetic structure are mating system (selfing vs. outcrossing) for nuclear markers and seed dispersal mode (gravity vs. the other categories) for maternally inherited markers. These two cases correspond to the most trivial distinctions in terms of dispersal of pollen and seeds: selfing represents the case of total lack of pollen gene flow, whereas the category gravity corresponds in fact to the absence of adaptation for seed dispersal. Although some LHT such as perenniality can still be used to predict the partitioning of genetic diversity at nuclear genes, we showed that their association with genetic structure is only indirect, mediated by evolutionary covariation with the mating system.

On the contrary, related species generally have similar levels of genetic structure at both maternally and biparentally inherited markers, to the extent that $77 \%-79 \%$ of all variation in $G_{\mathrm{ST}}$ is accounted for by species' taxonomic classification. However, it is difficult to imagine that genetic structure itself could be directly inherited across species following speciation. Rather, phenotypic traits affecting gene flow appear to be the most likely causes of this marked similarity in the organization of genetic structure of closely related taxa. Nevertheless, genetic structure did not show evolutionary correlations with most LHT in our study of seed plants: only a few LHT such as mating system (for nuclear markers) and seed dispersal mode or geographic range (for organelle markers) had explanatory power for interspecific variation in genetic structure within an explicit evolutionary scenario. This paradox can be explained if we consider that LHT do affect genetic structure but in ways that depend largely on the particular context (historical, ecological, and especially taxonomical). These contingencies have been previously emphasized to explain why there are so few traits consistently affecting the diversification of plant lineages (de Queiroz 2002).

Efforts by ecologists to identify traits that can help predict the fate of a species (e.g., whether it will become invasive or will remain rare and whether it will diversify by speciation or become extinct) have also been met with relatively little success. For instance, Stebbins (1965) was unable to find attributes common to plants that have become weeds in California. Subsequently, several authors have shown little optimism that single organisms' features may indicate their potential of invasiveness and have attributed this to the idiosyncrasy of each invasion (e.g., Goodwin et al. 1999; Muth and Pigliucci 2006). Other researchers remain optimistic regarding the possibility to predict invasions but stress the need to better specify the context where this will apply (e.g., Hamilton et al. 2005). The difficulty to identify universal constraints on basic species properties such as invasiveness or genetic structure should probably not come as a surprise. It simply illustrates the numerous strategies that exist for the successful expansion and diversification of species on Earth.

\section{Acknowledgments}

We are grateful to F. Gugerli, S. Mariette, E. Rezende, and two anonymous reviewers for their critical comments on a previous version of the manuscript. We thank P. GarnierGéré for her help on nested comparative analysis. We thank I. Aguinagalde, J. Arroyo, J. Bain, S. Barrett, M. Beilstein, M. Byrne, M. A. Cardoso, P. Carmen, E. Collin, S. Cozzolino, N. Devos, R. Diaz-Delgado, C. Dutech, J. Felsenstein, T. Garland Jr., J. A. Godoy, C. Gonnelli, B. L. Gross, B. Hahn, M. Hamilton, M. Hedrén, J. Holman, S.-Y. Hwang, A. Jones, M. Koch, M. Konnert, T. Lacombe, M. Lascoux, E. Martins, A. Meade, A. Mengoni, A. Merchant, B. Musch, C. Navarro, N. Ollat, S. Ollier, D. Prat, J. Provan, A. Purvis, F. Salgueiro, L. G. Sanchez, J. G. Seguarra Moragues, D. Soltis, D. Steane, I. Stehlik, N. Tani, J. Tibbits, R. Timme, S. Trewick, R. Vaillancourt, L. Wallace, A. Widmer, P. Wolf, and A. Wolfe for providing information on LHT or on phylogenetic relationships of the species. The research was supported by grants from the European Commission research program FAIR5-CT97-3795, by the Bureau des Ressources Génétiques to R.J.P., and by the Spanish Ministry of Education (grant REN2003-00273) and RNM-305 (Junta de Andalucía) to P.J. We also acknowledge support to J.D. from the Marie Curie RT5 postdoctoral training facility at Estación Biológica de Doñana (Consejo Superior de Investigaciones Científicas) and support from projects BOS2002-01162 and 025383ACORDISP to A.H.

\section{Literature Cited}

Abouheif, E. 1999. A method for testing the assumption of phylogenetic independence in comparative data. Evolutionary Ecology Research 1:895-909.

Ackerly, D. D. 2000. Taxon sampling, correlated evolution, and independent contrast. Evolution 54:1480-1492. 
Aguinagalde, I., A. Hampe, A. Mohanty, J. P. Martin, J. Duminil, and R. J. Petit. 2005. Effects of life history traits and species distribution on genetic structure at maternally inherited markers in European trees and shrubs. Journal of Biogeography 32:329-339.

Arduino, P., F. Verra, R. Cianchi, W. Rossi, B. Corrias, and L. Bullini. 1996. Genetic variation and natural hybridization between Orchis laxiflora and Orchis palustris (Orchidaceae). Plant Systematics and Evolution 202:87-109.

Austerlitz, F., S. Mariette, N. Machon, P. H. Gouyon, and B. Godelle. 2000. Effects of colonization processes on genetic diversity: differences between annual plants and tree species. Genetics 154: 1309-1321.

Barrett, S. C. H. 1998. The evolution of mating strategies in flowering plants. Trends in Plant Science 3:335-341.

Barrett, S. C. H., L. D. Harder, and A. C. Worley. 1996. The comparative biology of pollination and mating in flowering plants. Philosophical Transactions of the Royal Society B: Biological Sciences 351:1271-1280.

Bell, G. 1989. A comparative method. American Naturalist 133:553571.

Bohonak, A. J. 1999. Dispersal, gene flow, and population structure. Quarterly Review of Biology 74:21-45.

Bossema, I. 1979. Jays and oaks: an eco-ethological study of a symbiosis. Behaviour 70:1-117.

Chambers, J. C., and J. A. MacMahon. 1994. A day in the life of a seed: movements and fates of seeds and their implications for natural and managed systems. Annual Review of Ecology and Systematics 25:263-292.

Charlesworth, D. 2003. Effects of inbreeding on the genetic diversity of populations. Philosophical Transactions of the Royal Society B: Biological Sciences 358:1051-1070.

Cole, C. T. 2003. Genetic variation in rare and common plants. Annual Review of Ecology Evolution and Systematics 34:213-237.

de Queiroz, A. 2002. Contingent predictability in evolution: key traits and diversification. Systematic Biology 51:917-929.

Eriksson, O., E. M. Friis, and P. Lofgren. 2000. Seed size, fruit size, and dispersal systems in angiosperms from the Early Cretaceous to the Late Tertiary. American Naturalist 156:47-58.

Felsenstein, J. 1985. Phylogenies and the comparative method. American Naturalist 125:1-15.

Freckleton, R. P., P. H. Harvey, and M. Pagel. 2002. Phylogenetic analysis and comparative data: a test and review of evidence. American Naturalist 160:712-726.

Garland, T., Jr., P. H. Harvey, and A. Ives. 1992. Procedures for the analysis of comparative data using phylogenetically independent contrasts. Systematic Biology 41:18-32.

Garland, T., Jr., A. F. Bennett, and E. L. Rezende. 2005. Phylogenetic approaches in comparative physiology. Journal of Experimental Biology 208:3015-3035.

Gitzendanner, M. A., and P. S. Soltis. 2000. Patterns of genetic variation in rare and widespread plant congeners. American Journal of Botany 87:783-792.

Goodwin, B. J., A. J. McAllister, and L. Fahrig. 1999. Predicting invasiveness of plant species based on biological information. Conservation Biology 13:422-426.

Greene, D. F., and E. A. Johnson. 1995. Long-distance wind dispersal of tree seeds. Canadian Journal of Botany 73:1036-1045.

Hamilton, M. A., B. R. Murray, M. W. Cadotte, G. C. Hose, A. C. Baker, C. J. Harris, and D. Licari. 2005. Life-history correlates of plant invasiveness at regional and continental scales. Ecology Letters 8:1066-1074.

Hampe, A. 2004. Extensive hydrochory uncouples spatiotemporal patterns of seedfall and seedling recruitment in a "bird-dispersed" riparian tree. Journal of Ecology 92:797-807.

Hamrick, J. L., and M. J. W. Godt. 1989. Allozyme diversity in plant species. Pages 43-63 in A. H. D. Brown, M. T. Clegg, A. L. Kahler, and B. S. Weir, eds. Plant population genetics, breeding and germplasm resources. Sinauer, Sunderland, MA.

. 1996. Effects of life history traits on genetic diversity in plant species. Philosophical Transactions of the Royal Society B: Biological Sciences 351:1291-1298.

Hamrick, J. L., and J. D. Nason. 1996. Consequences of dispersal in plants. Pages 203-236 in O. E. Rhodes, R. K. Chesser, and M. H. Smith, eds. Population dynamics in ecological space and time. University of Chicago Press, Chicago.

Hamrick, J. L., M. J. W. Godt, M. D. A. Murawski, and M. D. Loveless. 1992. Factors influencing levels of genetic diversity in woody plant species. New Forests 6:95-124.

Hamrick, J. L., D. A. Murawski, and J. D. Nason. 1993. The influence of seed dispersal mechanisms on the genetic structure of tropical tree populations. Vegetatio 107/108:281-297.

Hedren, M. 2001. Systematics of the Dactylorhiza euxina/incarnata/ maculata polyploid complex (Orchidaceae) in Turkey: evidence from allozyme data. Plant Systematics and Evolution 229:23-44.

Hedren, M., M. F. Fay, and M. W. Chase. 2001. Amplified fragment length polymorphisms (AFLP) reveal details of polyploid evolution in Dactylorhiza (Orchidaceae). American Journal of Botany 88: $1868-1880$

Hewitt, G. 2000. The genetic legacy of the Quaternary ice ages. Nature 405:907-913.

Higgins, S. I., S. Lavorel, and E. Revilla. 2003. Estimating plant migration rates under habitat loss and fragmentation. Oikos 101: 354-366.

Housworth, E. A., E. P. Martins, and M. Lynch. 2004. The phylogenetic mixed model. American Naturalist 163:84-96.

Ihaka, A., and R. Gentleman. 1996. R: a language for data analysis and graphics. Journal of Computational and Graphical Statistics 5:299-314.

Jordano, P. 1995. Angiosperm fleshy fruits and seed dispersers: a comparative analysis of adaptation and constraints in plant-animal interactions. American Naturalist 145:163-191.

Liston, A., W. A. Robinson, D. Pinero, and E. R. Alvarez-Buylla. 1999. Phylogenetics of Pinus (Pinaceae) based on nuclear ribosomal DNA internal transcribed spacer region sequences. Molecular Phylogenetics and Evolution 11:95-109.

Loveless, M. D., and J. L. Hamrick. 1984. Ecological determinants of genetic structure in plant populations. Annual Review of Ecology and Systematics 15:65-95.

Manos, P. S., J. J. Doyle, and K. C. Nixon. 1999. Phylogeny, biogeography, and processes of molecular differentiation in Quercus subgenus Quercus (Fagaceae). Molecular Phylogenetics and Evolution 12:333-349.

Martins, E. P., and T. Garland Jr. 1991. Phylogenetic analyses of the correlated evolution of continuous characters: a simulation study. Evolution 45:534-557.

Moles, A. T., D. D. Ackerly, C. O. Webb, J. C. Tweddle, J. B. Dickie, and M. Westoby. 2005. A brief history of seed size. Science 307: 576-580. 
Morales, E. 2000. Estimating phylogenetic inertia in Thitonia (Asteraceae): a comparative approach. Evolution 54:475-484.

Moyle, L. C. 2006. Correlates of genetic differentiation and isolation by distance in 17 congeneric Silene species. Molecular Ecology 15: 1067-1081.

Muth, N. Z., and M. Pigliucci. 2006. Traits of invasives reconsidered: phenotypic comparisons of introduced invasives and introduced noninvasive plant species within two closely related clades. American Naturalist 93:188-196.

Nybom, H. 2004. Comparison of different nuclear DNA markers for estimating intraspecific genetic diversity in plants. Molecular Ecology 13:1143-1155.

Nybom, H., and I. V. Bartish. 2000. Effects of life history traits and sampling strategies on genetic diversity estimates obtained with RAPD markers in plants. Perspectives in Plant Ecology Evolution and Systematics 3/2:93-114.

Pacheco, L. F., and J. A. Simonetti. 2000. Genetic structure of a mimosoid tree deprived of its seed disperser, the spider monkey. Conservation Biology 14:1766-1775.

Paradis, E., and J. Claude. 2002. Analysis of comparative data using generalized estimating equations. Journal of Theoretical Biology 218:175-185.

Petit, R. J., and G. G. Vendramin. 2006. Phylogeography of organelle DNA in plants: an introduction. Pages 23-97 in S. Weiss and N. Ferrand, eds. Phylogeography of southern European refugia. Springer, Vienna.

Petit, R. J., I. Aguinagalde, J. L. de Beaulieu, C. Bittkau, S. Brewer, R. Cheddadi, R. Ennos, et al. 2003. Glacial refugia: hotspots but not melting pots of genetic diversity. Science 300:1563-1565.

Petit, R. J., A. Hampe, and R. Cheddadi. 2005a. Climate changes and tree phylogeography in the Mediterranean. Taxon 54:877-885.

Petit, R. J., J. Duminil, S. Fineschi, A. Hampe, D. Salvini, and G. G. Vendramin. 2005b. Comparative organisation of chloroplast, mitochondrial and nuclear diversity in plant populations. Molecular Ecology 14:689-711.

Purvis, A., and A. Rambaud. 1995. Comparative analysis by independent contrasts (CAIC): an Apple Macintosh application for analysis of comparative data. Computer Applications in the Biosciences 11:247-251.

Rees, M., R. Condit, M. Crawley, S. Pacala, and D. Tilman. 2001. Long-term studies of vegetation dynamics. Science 293:650-655.

Renner, S. S., and R. E. Ricklefs. 1995. Dioecy and its correlates in the flowering plants. American Journal of Botany 82:596-606.
Rieseberg, L. H. 1991. Homoploid reticulate evolution in Helianthus (Asteraceae): evidence from ribosomal genes. American Journal of Botany 78:1218-1237.

Schilling, E. E., and C. R. Linder. 1998. Phylogenetic relationships in Helianthus (Asteraceae) based on nuclear ribosomal DNA internal transcribed spacer region sequence data. Systematic Botany 23:177-187.

Soltis, D. E., P. S. Soltis, M. W. Chase, M. E. Mort, D. C. Albach, M. Zanis, V. Savolainen, et al. 2000. Angiosperm phylogeny inferred from $18 \mathrm{~S} \mathrm{rDNA}, r b c \mathrm{~L}$, and $a t p \mathrm{~B}$ sequences. Botanical Journal of the Linnean Society 133:381-461.

Soltis, D. E., R. K. Kuzoff, M. E. Mort, M. Zanis, M. Fishbein, L. Hufford, J. Koontz, and M. K. Arroyo. 2001. Elucidating deeplevel phylogenetic relationships in Saxifragaceae using sequences for six chloroplastic and nuclear DNA regions. Annals of the Missouri Botanical Garden 88:669-693.

Stebbins, G. L. 1965. Colonizing species of the native California flora. Pages 173-191 in H. G. Baker and L. G. Stebbins, eds. The genetics of colonizing species. Academic Press, New York.

SYSTAT. 2002. SYSTAT for Windows. Version 10.2. Statistics. SYSTAT, Evanston, IL.

Vamosi, J. C., S. P. Otto, and S. C. H. Barrett. 2003. Phylogenetic analysis of the ecological correlates of dioecy in angiosperms. Journal of Evolutionary Biology 16:1006-1018.

Vogler, D. W., and S. Kalisz. 2001. Sex among the flowers: the distribution of plant mating systems. Evolution 55:202-204.

Wahlund, S. 1928. Zusammensetzung von Population und Korrelationserscheinung vom Standpunkt der Vererbungslehre aus betrachtet. Hereditas 11:65-106.

Wang, B. C., and T. B. Smith. 2002. Closing the seed dispersal loop. Trends in Ecology \& Evolution 17:379-385.

Wang, X. R., and A. E. Szmidt. 1993. Chloroplast DNA-based phylogeny of Asian Pinus species (Pinaceae). Plant Systematics and Evolution 188:197-211.

Westoby, M., M. Leishman, and J. Lord. 1996. Comparative ecology of seed size and dispersal. Philosophical Transactions of the Royal Society B: Biological Sciences 351:1309-1317.

Wright, S. 1951. The genetical structure of populations. Annals of Eugenics 15:323-354.

- 1965. The interpretation of population structure by Fstatistics with special regards to systems of mating. Evolution 19: 395-420.

Associate Editor and Editor: Michael C. Whitlock 


\section{Appendix A from J. Duminil et al., "Can Population Genetic Structure Be Predicted from Life-History Traits?'}

(Am. Nat., vol. 169, no. 5, p. 662)

Table A1

Life-history traits and genetic structure for all species studied

\begin{tabular}{|c|c|c|c|c|c|c|c|c|c|c|c|c|c|c|c|c|c|}
\hline Species & $\begin{array}{l}\text { Taxonomic } \\
\text { status }\end{array}$ & Subclass & Order & Family & Perenniality & $\begin{array}{l}\text { Growth } \\
\text { form }\end{array}$ & $\begin{array}{c}\text { Breeding } \\
\text { system }\end{array}$ & $\begin{array}{l}\text { Pollination } \\
\text { mode }\end{array}$ & $\begin{array}{c}\text { Seed } \\
\text { dispersal } \\
\text { mode }\end{array}$ & $\begin{array}{l}\text { Reproduction } \\
\text { type }\end{array}$ & $\begin{array}{l}\text { Mating } \\
\text { system }\end{array}$ & $\begin{array}{c}\text { Geographic } \\
\text { range }\end{array}$ & $\begin{array}{c}\text { Seed } \\
\text { mass } \\
\left(\mathrm{mg} \mathrm{seed}^{-1}\right)\end{array}$ & $\begin{array}{l}\text { Size } \\
(\mathrm{m})\end{array}$ & $G_{\mathrm{STm}}$ & $G_{\mathrm{STb}}$ & $F_{\mathrm{IS}}$ \\
\hline Abies alba & G & Coniferopsida & Coniferales & Pinaceae & LP & $\mathrm{T}$ & $\mathrm{H}$ & A & W & $\mathrm{s}$ & $\mathrm{O}$ & W & 76.800 & 45 & .92 & .09 & .05 \\
\hline Abies firma & G & Coniferopsida & Coniferales & Pinaceae & LP & $\mathrm{T}$ & $\mathrm{H}$ & A & $\mathrm{W}$ & $\mathrm{S}$ & $\mathrm{O}$ & $\mathrm{E}$ & 40.290 & 45 & .86 & & \\
\hline Abies homolepis & G & Coniferopsida & Coniferales & Pinaceae & LP & $\mathrm{T}$ & $\mathrm{H}$ & A & W & $\mathrm{S}$ & $\mathrm{O}$ & E & 15.500 & 24 & .47 & & \\
\hline Abies sachalinensis & G & Coniferopsida & Coniferales & Pinaceae & LP & $\mathrm{T}$ & $\mathrm{H}$ & A & W & $\mathrm{s}$ & $\mathrm{O}$ & $\mathrm{E}$ & 9.320 & 25 & .56 & .02 & .09 \\
\hline Acacia acuminata & D & Rosidae & Fabales & Fabaceae & LP & $\mathrm{s}$ & $\mathrm{H}$ & $\mathrm{E}$ & $\ldots$ & $\ldots$ & $\mathrm{O}$ & $\mathrm{R}$ & 16.200 & 5 & .40 & .10 & .33 \\
\hline Acer campestre & D & Rosidae & Sapindales & Aceraceae & LP & $\mathrm{T}$ & $\mathrm{H}$ & EA & W & $\mathrm{s}$ & $\mathrm{O}$ & W & 111.000 & 15 & .70 & & \\
\hline Acer pseudoplatanus & D & Rosidae & Sapindales & Aceraceae & LP & $\mathrm{T}$ & $\mathrm{H}$ & EA & AI & $\mathrm{s}$ & $\mathrm{O}$ & W & 109.600 & 30 & .67 & & \\
\hline Allium vineale & M & Liliidae & Asparagales & Alliaceae & SP & G & $\mathrm{H}$ & $\mathrm{E}$ & G & $\mathrm{v}$ & $\mathrm{O}$ & $\mathrm{W}$ & 1.000 & 1 & .76 & .39 & \\
\hline Alnus cordata & $\mathrm{D}$ & Rosidae & Fagales & Betulaceae & LP & $\mathrm{T}$ & $\mathrm{H}$ & A & W & $\mathrm{s}$ & $\mathrm{O}$ & $\mathrm{N}$ & 6.800 & 18 & 1.00 & .12 & \\
\hline Alnus glutinosa & D & Rosidae & Fagales & Betulaceae & LP & $\mathrm{T}$ & $\mathrm{H}$ & A & $\mathrm{W}$ & $\mathrm{S}$ & $\mathrm{O}$ & $\mathrm{w}$ & 2.100 & 18 & .87 & .20 & .10 \\
\hline Alyssum bertolonii & D & Rosidae & Brassicales & Brassicaceae & SP & $\mathrm{F}$ & $\mathrm{H}$ & A & G & $\ldots$ & $\ldots$ & E & .559 & .25 & .21 & & \\
\hline Anacamptis palustris & M & Liliidae & Asparagales & Orchidaceae & SP & $\mathrm{F}$ & $\mathrm{H}$ & $\mathrm{E}$ & $\mathrm{W}$ & $\mathrm{v}$ & $\mathrm{O}$ & $\ldots$ & .001 & 1.35 & .87 & .18 & .00 \\
\hline Aquilegia chrysantha & D & Magnoliidae & Ranunculales & Ranunculaceae & SP & $\mathrm{F}$ & $\mathrm{H}$ & $\mathrm{E}$ & G & $\mathrm{s}$ & OS & $\mathrm{N}$ & 1.037 & .61 & .87 & & \\
\hline Aquilegia longissima & D & Magnoliidae & Ranunculales & Ranunculaceae & SP & $\mathrm{F}$ & $\mathrm{H}$ & $\mathrm{E}$ & G & $\mathrm{S}$ & os & $\mathrm{N}$ & 1.037 & .61 & .89 & & \\
\hline Arabidopsis thaliana & D & Rosidae & Brassicales & Brassicaceae & A & $\mathrm{F}$ & $\mathrm{H}$ & E & G & $\mathrm{S}$ & $\mathrm{S}$ & W & .020 & .3 & .97 & .62 & .99 \\
\hline Arabis holboellii & D & Rosidae & Brassicales & Brassicaceae & SP & $\mathrm{F}$ & $\mathrm{H}$ & $\mathrm{E}$ & G & $\mathrm{V}$ & OS & $\mathrm{R}$ & .213 & 1 & .61 & & \\
\hline Argania spinosa & D & Asteridae & Ericales & Sapotaceae & LP & $\mathrm{T}$ & $\mathrm{H}$ & $\mathrm{E}$ & AI & $\mathrm{s}$ & $\mathrm{O}$ & $\mathrm{N}$ & $3,000.000$ & 10 & .60 & .18 & .10 \\
\hline Aucoumea klaineana & D & Rosidae & Sapindales & Burseraceae & LP & $\mathrm{T}$ & $\mathrm{D}$ & E & $\mathrm{W}$ & $\ldots$ & $\mathrm{O}$ & $\mathrm{N}$ & 98.000 & 45 & .60 & .14 & .15 \\
\hline Beta vulgaris & D & Caryophyllidae & Caryophyllales & Chenopodiaceae & B & $\mathrm{F}$ & G & A & W & $\mathrm{s}$ & $\mathrm{O}$ & W & 5.000 & 2 & .49 & .10 & .22 \\
\hline Betula nana & D & Rosidae & Fagales & Betulaceae & LP & $\mathrm{S}$ & $\mathrm{H}$ & A & $\mathrm{W}$ & $\mathrm{S}$ & $\ldots$ & w & .200 & 1 & .54 & & \\
\hline Betula pendula & D & Rosidae & Fagales & Betulaceae & LP & $\mathrm{T}$ & $\mathrm{H}$ & A & W & $\mathrm{s}$ & $\mathrm{O}$ & W & .250 & 24 & .41 & .03 & \\
\hline Betula pubescens & D & Rosidae & Fagales & Betulaceae & LP & $\mathrm{T}$ & $\mathrm{H}$ & A & $\mathrm{W}$ & $\mathrm{S}$ & $\mathrm{O}$ & $\mathrm{W}$ & .200 & 20 & .30 & & \\
\hline Caesalpinia echinata & D & Rosidae & Fabales & Fabaceae & LP & $\mathrm{T}$ & $\mathrm{H}$ & $\mathrm{E}$ & G & $\ldots$ & $\mathrm{O}$ & W & 303.000 & 15 & .91 & .58 & \\
\hline Calluna vulgaris & D & Asteridae & Ericales & Ericaceae & LP & $\mathrm{S}$ & $\mathrm{H}$ & EA & $\ldots$ & $\mathrm{V}$ & OS & W & .030 & .8 & .47 & .05 & .06 \\
\hline
\end{tabular}




\begin{tabular}{|c|c|c|c|c|c|c|c|c|c|c|c|c|c|c|c|c|c|}
\hline Species & $\begin{array}{l}\text { Taxonomic } \\
\text { status }\end{array}$ & Subclass & Order & Family & Perenniality & $\begin{array}{l}\text { Growth } \\
\text { form }\end{array}$ & $\begin{array}{l}\text { Breeding } \\
\text { system }\end{array}$ & $\begin{array}{l}\text { Pollination } \\
\text { mode }\end{array}$ & $\begin{array}{c}\text { Seed } \\
\text { dispersal } \\
\text { mode }\end{array}$ & $\begin{array}{l}\text { Reproduction } \\
\text { type }\end{array}$ & $\begin{array}{l}\text { Mating } \\
\text { system }\end{array}$ & $\begin{array}{l}\text { Geographic } \\
\text { range }\end{array}$ & $\begin{array}{c}\text { Seed } \\
\text { mass } \\
\left(\mathrm{mg} \mathrm{seed}^{-1}\right)\end{array}$ & $\begin{array}{l}\text { Size } \\
(\mathrm{m})\end{array}$ & $G_{\mathrm{STm}}$ & $G_{\mathrm{STb}}$ & $F_{\mathrm{IS}}$ \\
\hline Carpinus betulus & $\mathrm{D}$ & Rosidae & Fagales & Betulaceae & LP & $\mathrm{T}$ & $\mathrm{H}$ & A & $\mathrm{W}$ & S & $\mathrm{O}$ & $\mathrm{W}$ & 35.500 & 20 & .97 & .07 & \\
\hline Carpinus orientalis & $\mathrm{D}$ & Rosidae & Fagales & Betulaceae & LP & S & $\mathrm{H}$ & A & $\mathrm{W}$ & S & $\mathrm{O}$ & $\mathrm{W}$ & 20.938 & 8 & 1.00 & & \\
\hline Caryocar brasiliense & $\mathrm{D}$ & Rosidae & Malpighiales & Caryocaraceae & LP & $\mathrm{T}$ & $\mathrm{H}$ & $\mathrm{Z}$ & G & $\ldots$ & $\mathrm{O}$ & $\mathrm{R}$ & 50.270 & 10 & .88 & .29 & .04 \\
\hline Castanea sativa & $\mathrm{D}$ & Rosidae & Fagales & Fagaceae & LP & $\mathrm{T}$ & $\mathrm{H}$ & EA & $\mathrm{AC}$ & S & $\mathrm{O}$ & $\mathrm{W}$ & $9,944.000$ & 35 & .43 & .20 & .21 \\
\hline Cedrela odorata & $\mathrm{D}$ & Rosidae & Sapindales & Meliaceae & LP & $\mathrm{T}$ & $\mathrm{H}$ & $\mathrm{E}$ & $\mathrm{W}$ & S & $\mathrm{O}$ & $\mathrm{R}$ & 17.000 & 30 & .96 & .55 & .00 \\
\hline Corallorhiza maculata & M & Liliidae & Orchidales & Orchidaceae & SP & F & $\mathrm{H}$ & E & $\mathrm{W}$ & $\mathrm{v}$ & $\mathrm{O}$ & $\mathrm{W}$ & .003 & .5 & .27 & & \\
\hline Coreopsis grandiflora & $\mathrm{D}$ & Asteridae & Asterales & Asteraceae & A & $\mathrm{F}$ & $\mathrm{H}$ & E & W & $\ldots$ & $\mathrm{O}$ & $\mathrm{R}$ & 2.580 & 91 & .64 & .07 & .00 \\
\hline Coreopsis nuecensis & $\mathrm{D}$ & Asteridae & Asterales & Asteraceae & A & F & $\mathrm{H}$ & E & $\mathrm{W}$ & $\ldots$ & $\mathrm{O}$ & $\mathrm{N}$ & 1.221 & $\ldots$ & .78 & .10 & .00 \\
\hline Corylus avellana & $\mathrm{D}$ & Rosidae & Fagales & Betulaceae & LP & $\mathrm{s}$ & $\mathrm{H}$ & A & $\mathrm{AI}$ & $\mathrm{s}$ & $\mathrm{O}$ & W & $1,262.400$ & 4.5 & .90 & .20 & .03 \\
\hline Corythophora alta & $\mathrm{D}$ & Asteridae & Ericales & Lecythidaceae & LP & $\mathrm{T}$ & $\mathrm{H}$ & E & $\mathrm{AC}$ & $\ldots$ & $\mathrm{O}$ & $\mathrm{R}$ & $\ldots$ & $\ldots$ & .96 & & \\
\hline Crataegus laevigata & $\mathrm{D}$ & Rosidae & Rosales & Rosaceae & LP & $\mathrm{s}$ & $\mathrm{H}$ & E & $\mathrm{AI}$ & $\mathrm{s}$ & $\mathrm{O}$ & W & 60.100 & 6 & .34 & & \\
\hline Crataegus monogyna & $\mathrm{D}$ & Rosidae & Rosales & Rosaceae & LP & S & $\mathrm{H}$ & E & AI & S & $\mathrm{O}$ & $\mathrm{W}$ & 66.000 & 8 & .24 & & \\
\hline Cytisus scoparius & $\mathrm{D}$ & Rosidae & Fabales & Fabaceae & LP & $\mathrm{s}$ & $\mathrm{H}$ & E & G & $\mathrm{s}$ & $\mathrm{O}$ & W & 8.300 & 2 & .57 & & \\
\hline Dactylis glomerata & $\mathrm{M}$ & Liliidae & Poales & Poaceae & SP & G & $\mathrm{D}$ & A & G & $\mathrm{V}$ & $\mathrm{O}$ & $\mathrm{W}$ & .850 & 1.2 & 1.00 & .23 & .00 \\
\hline $\begin{array}{l}\text { Dactylorhiza incarnatal } \\
\text { maculata }\end{array}$ & M & Liliidae & Asparagales & Orchidaceae & SP & F & $\mathrm{H}$ & E & $\mathrm{W}$ & $\mathrm{v}$ & $\mathrm{O}$ & $\mathrm{W}$ & .001 & .7 & .66 & .10 & \\
\hline Dicorynia guianensis & $\mathrm{D}$ & Rosidae & Fabales & Fabaceae & LP & $\mathrm{T}$ & $\mathrm{H}$ & E & $\mathrm{W}$ & S & OS & E & 500.000 & 50 & .41 & .04 & -.18 \\
\hline Draba aizoides & $\mathrm{D}$ & Rosidae & Brassicales & Brassicaceae & SP & $\mathrm{F}$ & $\mathrm{H}$ & E & G & $\ldots$ & $\mathrm{O}$ & $\mathrm{R}$ & .058 & .1 & .29 & & \\
\hline Dryas integrifolia & $\mathrm{D}$ & Rosidae & Rosales & Rosaceae & SP & F & $\mathrm{H}$ & E & $\mathrm{W}$ & $\mathrm{v}$ & $\mathrm{O}$ & $\mathrm{W}$ & .400 & .15 & .44 & & \\
\hline Dunnia sinensis & $\mathrm{D}$ & Asteridae & Gentianales & Rubiaceae & LP & S & $\mathrm{H}$ & E & W & $\ldots$ & $\mathrm{O}$ & $\mathrm{E}$ & $\ldots$ & $\ldots$ & .65 & & \\
\hline Epipactis helleborine & M & Liliidae & Orchidales & Orchidaceae & SP & $\mathrm{F}$ & $\mathrm{H}$ & E & $\mathrm{W}$ & v & OS & $\mathrm{W}$ & .003 & .8 & .44 & & \\
\hline Eritrichium nanum & $\mathrm{D}$ & Asteridae & Lamiales & Boraginaceae & SP & F & $\mathrm{H}$ & E & G & $\ldots$ & OS & E & $\ldots$ & .08 & 1.00 & .19 & \\
\hline $\begin{array}{l}\text { Eucalyptus angustissima } \\
\text { complex }\end{array}$ & $\mathrm{D}$ & Rosidae & Myrtales & Myrtaceae & LP & $\mathrm{T}$ & $\mathrm{H}$ & E & G & S & $\mathrm{O}$ & E & 1.500 & 8 & .98 & .11 & .04 \\
\hline $\begin{array}{l}\text { Eucalyptus brownii/ } \\
\text { populnea complex }\end{array}$ & $\mathrm{D}$ & Rosidae & Myrtales & Myrtaceae & LP & $\mathrm{T}$ & $\mathrm{H}$ & $\mathrm{EZ}$ & $\mathrm{W}$ & S & $\mathrm{O}$ & E & .560 & 12 & .35 & .05 & .30 \\
\hline Eucalyptus kochii & $\mathrm{D}$ & Rosidae & Myrtales & Myrtaceae & LP & $\mathrm{T}$ & $\mathrm{H}$ & $\mathrm{E}$ & $\mathrm{W}$ & s & $\mathrm{O}$ & E & 2.220 & 5 & .66 & .05 & .08 \\
\hline Eucalyptus nitens & $\mathrm{D}$ & Rosidae & Myrtales & Myrtaceae & LP & $\mathrm{T}$ & $\mathrm{H}$ & $\mathrm{EZ}$ & $\mathrm{W}$ & S & $\mathrm{O}$ & $\mathrm{N}$ & 2.800 & 36 & .62 & .30 & .31 \\
\hline Eugenia uniflora & $\mathrm{D}$ & Rosidae & Myrtales & Myrtaceae & LP & $\mathrm{T}$ & $\mathrm{H}$ & $\mathrm{E}$ & $\ldots$ & $\mathrm{v}$ & $\mathrm{O}$ & E & 4.000 & 10 & .26 & .21 & \\
\hline Fagus crenata & $\mathrm{D}$ & Rosidae & Fagales & Fagaceae & LP & $\mathrm{T}$ & $\mathrm{H}$ & A & $\mathrm{AC}$ & S & $\mathrm{O}$ & $\mathrm{N}$ & 178.570 & 40 & .97 & .04 & .03 \\
\hline Fagus sylvatica & $\mathrm{D}$ & Rosidae & Fagales & Fagaceae & LP & $\mathrm{T}$ & $\mathrm{H}$ & A & $\mathrm{AC}$ & S & $\mathrm{O}$ & $\mathrm{W}$ & 274.100 & 35 & .83 & .06 & .02 \\
\hline Frangula alnus & $\mathrm{D}$ & Rosidae & Rosales & Rhamnaceae & LP & s & $\mathrm{H}$ & E & $\mathrm{AI}$ & S & $\mathrm{O}$ & $\mathrm{W}$ & 17.500 & 5 & .79 & & \\
\hline Fraxinus angustifolia & D & Asteridae & Lamiales & Oleaceae & LP & $\mathrm{T}$ & D & A & $\mathrm{W}$ & $\mathrm{s}$ & & $\mathrm{W}$ & 53.400 & 25 & .94 & & \\
\hline Fraxinus excelsior & $\mathrm{D}$ & Asteridae & Lamiales & Oleaceae & LP & $\mathrm{T}$ & $\mathrm{D}$ & A & $\mathrm{W}$ & S & $\mathrm{O}$ & $\mathrm{W}$ & 76.300 & 35 & .85 & .09 & .01 \\
\hline Gliricidia sepium & $\mathrm{D}$ & Rosidae & Fabales & Fabaceae & LP & $\mathrm{T}$ & $\mathrm{H}$ & E & G & $\ldots$ & $\mathrm{O}$ & $\mathrm{R}$ & 103.000 & 12 & .69 & .17 & .02 \\
\hline Glycine soja & $\mathrm{D}$ & Rosidae & Fabales & Fabaceae & A & $\mathrm{F}$ & $\mathrm{H}$ & $\mathrm{E}$ & AI & S & S & $\mathrm{R}$ & 48.019 & $\ldots$ & .52 & .48 & 1.00 \\
\hline Gymnadenia conopsea & M & Liliidae & Orchidales & Orchidaceae & SP & $\mathrm{F}$ & $\mathrm{H}$ & E & $\mathrm{W}$ & $\mathrm{V}$ & $\mathrm{O}$ & $\mathrm{W}$ & .008 & .65 & .33 & .45 & .73 \\
\hline Hedera helix s.l. & $\mathrm{D}$ & Asteridae & Apiales & Araliaceae & LP & $\mathrm{V}$ & $\mathrm{H}$ & E & AI & $\mathrm{V}$ & $\mathrm{O}$ & W & 21.600 & 30 & .64 & & \\
\hline
\end{tabular}


Table A1 (Continued)

\begin{tabular}{|c|c|c|c|c|c|c|c|c|c|c|c|c|c|c|c|c|c|}
\hline Species & $\begin{array}{c}\text { Taxonomic } \\
\text { status }\end{array}$ & Subclass & Order & Family & Perenniality & $\begin{array}{l}\text { Growth } \\
\text { form }\end{array}$ & $\begin{array}{l}\text { Breeding } \\
\text { system }\end{array}$ & $\begin{array}{l}\text { Pollination } \\
\text { mode }\end{array}$ & $\begin{array}{c}\text { Seed } \\
\text { dispersal } \\
\text { mode }\end{array}$ & $\begin{array}{l}\text { Reproduction } \\
\text { type }\end{array}$ & $\begin{array}{l}\text { Mating } \\
\text { system }\end{array}$ & $\begin{array}{l}\text { Geographic } \\
\text { range }\end{array}$ & $\begin{array}{c}\text { Seed } \\
\text { mass } \\
\left(\text { mg seed }^{-1}\right)\end{array}$ & $\begin{array}{l}\text { Size } \\
(\mathrm{m})\end{array}$ & $G_{\mathrm{STm}}$ & $G_{\text {Sть }}$ & $F_{\mathrm{IS}}$ \\
\hline Helianthus anпииs & $\mathrm{D}$ & Asteridae & Asterales & Asteraceae & A & $\mathrm{F}$ & $\mathrm{H}$ & $\mathrm{E}$ & AA & $\mathrm{S}$ & $\mathrm{O}$ & $\mathrm{R}$ & 44.500 & 3.5 & .76 & .16 & \\
\hline Helianthus deserticola & D & Asteridae & Asterales & Asteraceae & A & F & $\mathrm{H}$ & E & AA & S & $\mathrm{O}$ & $\mathrm{R}$ & 5.300 & .4 & .73 & .25 & \\
\hline Helianthus petiolaris & D & Asteridae & Asterales & Asteraceae & A & F & $\mathrm{H}$ & E & AA & S & $\mathrm{O}$ & $\mathrm{W}$ & 2.000 & 1 & .49 & .19 & \\
\hline Hieracium pilosella agg. & $\mathrm{D}$ & Asteridae & Asterales & Asteraceae & SP & $\mathrm{F}$ & $\mathrm{H}$ & E & $\mathrm{W}$ & $\mathrm{v}$ & $\ldots$ & $\mathrm{R}$ & .220 & .3 & .33 & & \\
\hline Hordeum vulgare & M & Liliidae & Poales & Poaceae & A & G & $\mathrm{H}$ & A & AA & $\mathrm{v}$ & $\mathrm{S}$ & $\mathrm{W}$ & 41.900 & 1.3 & .75 & .48 & 1.00 \\
\hline Ilex aquifolium & $\mathrm{D}$ & Rosidae & Aquifoliales & Aquifoliaceae & LP & $\mathrm{T}$ & $\mathrm{D}$ & E & AI & $\mathrm{v}$ & $\mathrm{O}$ & $\mathrm{w}$ & 103.000 & 15 & .60 & & \\
\hline $\begin{array}{l}\text { Ipomopsis aggregata } \\
\text { complex }\end{array}$ & D & Asteridae & Ericales & Polemoniaceae & SP & $\mathrm{F}$ & $\mathrm{H}$ & $\mathrm{Z}$ & AI & $\ldots$ & $\mathrm{O}$ & $\mathrm{R}$ & 2.071 & .4 & 1.00 & .15 & .06 \\
\hline Kandelia candel & $\mathrm{D}$ & Rosidae & Malpighiales & Rhizophoraceae & LP & $\mathrm{T}$ & $\mathrm{H}$ & E & $\ldots$ & $\ldots$ & os & $\mathrm{R}$ & $\ldots$ & 8 & .42 & .06 & .02 \\
\hline Lambertia orbifolia & D & Rosidae & Proteales & Proteaceae & LP & s & $\mathrm{H}$ & $\mathrm{z}$ & AA & $\ldots$ & os & $\mathrm{N}$ & 20.000 & 5 & .84 & .44 & .32 \\
\hline Larix olgensis & G & Coniferopsida & Coniferales & Pinaceae & LP & $\mathrm{T}$ & $\mathrm{H}$ & A & $\mathrm{W}$ & $\mathrm{S}$ & $\mathrm{O}$ & $\mathrm{W}$ & 6.650 & 30 & .55 & & \\
\hline Larix sibirica & G & Coniferopsida & Coniferales & Pinaceae & LP & $\mathrm{T}$ & $\mathrm{H}$ & A & $\mathrm{W}$ & S & $\mathrm{O}$ & $\mathrm{w}$ & 9.600 & 25 & .59 & .08 & \\
\hline Lolium perenne & M & Liliidae & Poales & Poaceae & SP & G & $\mathrm{H}$ & A & $\mathrm{G}$ & $\mathrm{v}$ & $\mathrm{O}$ & $\mathrm{W}$ & 1.790 & .9 & .38 & .11 & .04 \\
\hline Lolium rigidum & M & Liliidae & Poales & Poaceae & SP & G & $\mathrm{H}$ & A & G & $\mathrm{v}$ & $\mathrm{O}$ & $\mathrm{W}$ & 2.280 & .5 & .41 & .17 & .09 \\
\hline Lupinus texensis & $\mathrm{D}$ & Rosidae & Fabales & Fabaceae & A & $\mathrm{F}$ & $\mathrm{H}$ & E & G & $\ldots$ & os & $\mathrm{N}$ & 32.200 & .45 & .86 & & \\
\hline Melaleuca alternifolia & D & Rosidae & Myrtales & Myrtaceae & LP & $\mathrm{T}$ & $\mathrm{H}$ & E & $\mathrm{w}$ & $\ldots$ & $\mathrm{O}$ & E & .590 & $\ldots$ & .91 & .12 & .04 \\
\hline Michelia formosana & D & Magnoliidae & Magnoliales & Magnoliaceae & LP & $\mathrm{T}$ & $\mathrm{H}$ & E & AI & $\ldots$ & $\ldots$ & $\mathrm{E}$ & 119.183 & 20 & .40 & .47 & \\
\hline Nothofagus nervosa & D & Rosidae & Fagales & Fagaceae & LP & $\mathrm{T}$ & $\mathrm{H}$ & A & $\mathrm{W}$ & $\mathrm{S}$ & $\mathrm{O}$ & $\mathrm{R}$ & 16.460 & 40 & 1.00 & .08 & .00 \\
\hline Olea europaea & D & Asteridae & Lamiales & Oleaceae & LP & $\mathrm{T}$ & $\mathrm{H}$ & E & AI & S & os & $\mathrm{w}$ & 221.000 & 12 & .55 & .25 & .00 \\
\hline Packera cana & $\mathrm{D}$ & Asteridae & Asterales & Asteraceae & SP & $\mathrm{F}$ & $\mathrm{H}$ & E & AA & $\ldots$ & $\mathrm{O}$ & $\mathrm{R}$ & .004 & .2 & .26 & & \\
\hline Packera contermina & D & Asteridae & Asterales & Asteraceae & SP & $\mathrm{F}$ & $\mathrm{H}$ & E & AA & $\ldots$ & $\mathrm{O}$ & $\mathrm{N}$ & .004 & .1 & .36 & & \\
\hline Packera pseudaurea & $\mathrm{D}$ & Asteridae & Asterales & Asteraceae & SP & $\mathrm{F}$ & $\mathrm{H}$ & E & $\mathrm{AA}$ & $\ldots$ & $\mathrm{O}$ & $\mathrm{R}$ & .004 & .4 & .11 & & \\
\hline Packera sanguisorboides & $\mathrm{D}$ & Asteridae & Asterales & Asteraceae & B & $\mathrm{F}$ & $\mathrm{H}$ & E & $\mathrm{W}$ & $\ldots$ & $\mathrm{O}$ & E & .004 & $\ldots$ & .69 & & \\
\hline Packera subnuda & $\mathrm{D}$ & Asteridae & Asterales & Asteraceae & SP & $\mathrm{F}$ & $\mathrm{H}$ & E & $\mathrm{AA}$ & $\ldots$ & $\mathrm{O}$ & $\mathrm{R}$ & .004 & .1 & 1.00 & & \\
\hline Parnassia palustris & D & Rosidae & Saxifragales & Saxifragaceae & SP & $\mathrm{F}$ & $\mathrm{H}$ & E & $\ldots$ & $\ldots$ & os & $\mathrm{W}$ & .030 & .2 & .74 & .16 & .05 \\
\hline Pedicularis chamissonis & D & Asteridae & Lamiales & Scrophulariaceae & SP & $\mathrm{F}$ & $\mathrm{H}$ & E & AA & $\ldots$ & $\mathrm{O}$ & $\mathrm{N}$ & .716 & .6 & .91 & & \\
\hline Phacelia dubia & $\mathrm{D}$ & Asteridae & Solanales & Hydrophyllaceae & A & $\mathrm{F}$ & $\mathrm{H}$ & E & AI & $\mathrm{S}$ & $\mathrm{O}$ & $\mathrm{R}$ & .800 & .4 & .61 & .02 & .22 \\
\hline Picea abies & G & Coniferopsida & Coniferales & Pinaceae & LP & $\mathrm{T}$ & $\mathrm{H}$ & A & $\mathrm{w}$ & s & $\mathrm{O}$ & $\mathrm{W}$ & 7.443 & 60 & .68 & .05 & .07 \\
\hline Picea mariana & G & Coniferopsida & Coniferales & Pinaceae & LP & $\mathrm{T}$ & $\mathrm{H}$ & A & $\mathrm{w}$ & $\mathrm{v}$ & $\mathrm{O}$ & $\mathrm{W}$ & 1.300 & 18 & .54 & .06 & -.07 \\
\hline Pinus albicaulis & G & Coniferopsida & Coniferales & Pinaceae & LP & $\mathrm{T}$ & $\mathrm{H}$ & A & $\mathrm{AC}$ & s & os & $\mathrm{R}$ & 147.800 & 18 & .84 & .06 & .35 \\
\hline Pinus chiapensis & $\mathrm{G}$ & Coniferopsida & Coniferales & Pinaceae & LP & $\mathrm{T}$ & $\mathrm{H}$ & A & $\ldots$ & S & $\mathrm{O}$ & E & 42.800 & 50 & .89 & .23 & \\
\hline Pinus contorta & G & Coniferopsida & Coniferales & Pinaceae & LP & $\mathrm{T}$ & $\mathrm{H}$ & A & $\mathrm{w}$ & $\mathrm{s}$ & $\mathrm{O}$ & $\mathrm{N}$ & 4.400 & 33 & .72 & .09 & \\
\hline Pinus densata & G & Coniferopsida & Coniferales & Pinaceae & LP & $\mathrm{T}$ & $\mathrm{H}$ & A & $\mathrm{w}$ & S & $\mathrm{O}$ & $\mathrm{N}$ & 42.800 & 23 & .91 & .09 & .07 \\
\hline Pinus flexilis & G & Coniferopsida & Coniferales & Pinaceae & LP & $\mathrm{T}$ & $\mathrm{H}$ & A & $\mathrm{AC}$ & s & $\mathrm{O}$ & $\mathrm{W}$ & 81.600 & 15 & .77 & .09 & .11 \\
\hline Pinus muricata & $\mathrm{G}$ & Coniferopsida & Coniferales & Pinaceae & LP & $\mathrm{T}$ & $\mathrm{H}$ & A & $\mathrm{W}$ & S & $\mathrm{O}$ & $\mathrm{E}$ & 13.680 & 25 & .75 & .45 & \\
\hline Pinus parviflora & G & Coniferopsida & Coniferales & Pinaceae & LP & $\mathrm{T}$ & $\mathrm{H}$ & A & $\mathrm{AC}$ & $\mathrm{s}$ & $\mathrm{O}$ & $\mathrm{R}$ & 94.700 & 20 & .89 & .04 & .12 \\
\hline Pinus pinaster & G & Coniferopsida & Coniferales & Pinaceae & LP & $\mathrm{T}$ & $\mathrm{H}$ & A & $\mathrm{w}$ & S & $\mathrm{O}$ & $\mathrm{R}$ & 53.520 & 30 & 1.00 & .17 & .00 \\
\hline Pinus ponderosa & G & Coniferopsida & Coniferales & Pinaceae & LP & $\mathrm{T}$ & $\mathrm{H}$ & A & $\mathrm{w}$ & $\mathrm{S}$ & $\mathrm{O}$ & $\mathrm{W}$ & 38.000 & 33 & .97 & .02 & .00 \\
\hline
\end{tabular}


Table A1 (Continued)

\begin{tabular}{|c|c|c|c|c|c|c|c|c|c|c|c|c|c|c|c|c|c|}
\hline Species & $\begin{array}{l}\text { Taxonomic } \\
\text { status }\end{array}$ & Subclass & Order & Family & Perenniality & $\begin{array}{l}\text { Growth } \\
\text { form }\end{array}$ & $\begin{array}{l}\text { Breeding } \\
\text { system }\end{array}$ & $\begin{array}{l}\text { Pollination } \\
\text { mode }\end{array}$ & $\begin{array}{c}\text { Seed } \\
\text { dispersal } \\
\text { mode }\end{array}$ & $\begin{array}{l}\text { Reproduction } \\
\text { type }\end{array}$ & $\begin{array}{l}\text { Mating } \\
\text { system }\end{array}$ & $\begin{array}{l}\text { Geographic } \\
\text { range }\end{array}$ & $\begin{array}{c}\text { Seed } \\
\text { mass } \\
\left(\text { mg seed }^{-1}\right)\end{array}$ & $\begin{array}{l}\text { Size } \\
(\mathrm{m})\end{array}$ & $G_{\mathrm{STm}}$ & $G_{\mathrm{STb}}$ & $F_{\mathrm{IS}}$ \\
\hline Pinus radiata & G & Coniferopsida & Coniferales & Pinaceae & LP & $\mathrm{T}$ & $\mathrm{H}$ & A & W & $\mathrm{s}$ & $\mathrm{O}$ & E & 31.900 & 35 & .74 & .16 & .01 \\
\hline Pinus sylvestris & G & Coniferopsida & Coniferales & Pinaceae & LP & $\mathrm{T}$ & $\mathrm{H}$ & A & $\mathrm{W}$ & S & $\mathrm{O}$ & $\mathrm{W}$ & 6.000 & 30 & .88 & .03 & -.01 \\
\hline Piriqueta caroliniana & D & Rosidae & Malpighiales & Turneraceae & SP & $\mathrm{F}$ & $\mathrm{H}$ & $\mathrm{E}$ & $\mathrm{AC}$ & $\mathrm{V}$ & $\mathrm{O}$ & $\mathrm{W}$ & $\ldots$ & $\ldots$ & .67 & & \\
\hline Platanthera aquilonis & M & Liliidae & Asparagales & Orchidaceae & SP & F & $\mathrm{H}$ & E & $\mathrm{W}$ & $\mathrm{V}$ & S & $\mathrm{W}$ & .001 & .8 & .84 & & \\
\hline Platanthera dilatata & M & Liliidae & Asparagales & Orchidaceae & SP & F & $\mathrm{H}$ & E & $\mathrm{W}$ & $\mathrm{v}$ & $\mathrm{O}$ & $\mathrm{W}$ & .001 & .9 & .68 & & \\
\hline Platanthera huronensis & M & Liliidae & Asparagales & Orchidaceae & SP & F & $\mathrm{H}$ & E & $\mathrm{W}$ & $\mathrm{v}$ & $\mathrm{O}$ & $\mathrm{W}$ & .001 & 1 & .61 & & \\
\hline Populus tremula & D & Rosidae & Malpighiales & Salicaceae & LP & $\mathrm{T}$ & $\mathrm{D}$ & A & W & $\mathrm{V}$ & $\mathrm{O}$ & $\mathrm{W}$ & .110 & 18 & .11 & & \\
\hline Primula cuneifolia & D & Asteridae & Ericales & Primulaceae & SP & $\mathrm{F}$ & $\mathrm{H}$ & E & $\mathrm{G}$ & S & os & $\mathrm{N}$ & 24.320 & .15 & 1.00 & & \\
\hline Prunus avium & D & Rosidae & Rosales & Rosaceae & LP & $\mathrm{T}$ & $\mathrm{H}$ & E & AI & $\mathrm{V}$ & $\mathrm{O}$ & $\mathrm{W}$ & 118.200 & 20 & .29 & .05 & .11 \\
\hline Prunus spinosa & D & Rosidae & Rosales & Rosaceae & LP & S & $\mathrm{H}$ & E & AI & $\mathrm{v}$ & $\mathrm{O}$ & $\mathrm{W}$ & 148.500 & 7 & .34 & & \\
\hline Pseudotsuga menziesii & G & Coniferopsida & Coniferales & Pinaceae & LP & $\mathrm{T}$ & $\mathrm{H}$ & A & W & $\mathrm{S}$ & $\mathrm{O}$ & $\mathrm{R}$ & 11.000 & 100 & .74 & .23 & \\
\hline Quercus alba complex & D & Rosidae & Fagales & Fagaceae & LP & $\mathrm{T}$ & $\mathrm{H}$ & A & $\mathrm{AC}$ & $\ldots$ & $\mathrm{O}$ & $\mathrm{W}$ & $3,173.000$ & 24 & .87 & .03 & .00 \\
\hline Quercus faginea & D & Rosidae & Fagales & Fagaceae & LP & $\mathrm{T}$ & $\mathrm{H}$ & A & $\mathrm{AC}$ & $\ldots$ & $\mathrm{O}$ & $\mathrm{R}$ & $2,560.056$ & 20 & .95 & & \\
\hline Quercus frainetto & D & Rosidae & Fagales & Fagaceae & LP & $\mathrm{T}$ & $\mathrm{H}$ & A & $\mathrm{AC}$ & S & $\mathrm{O}$ & $\mathrm{R}$ & $2,560.056$ & 30 & .83 & & \\
\hline Quercus glauca & D & Rosidae & Fagales & Fagaceae & LP & $\mathrm{T}$ & $\mathrm{H}$ & E & $\mathrm{AC}$ & $\ldots$ & $\mathrm{O}$ & $\mathrm{R}$ & 526.320 & 15 & .56 & & \\
\hline Quercus ilex & D & Rosidae & Fagales & Fagaceae & LP & $\mathrm{T}$ & $\mathrm{H}$ & A & $\mathrm{AC}$ & S & $\mathrm{O}$ & $\mathrm{W}$ & $2,311.000$ & 20 & .92 & .10 & .05 \\
\hline Quercus petraea & D & Rosidae & Fagales & Fagaceae & LP & $\mathrm{T}$ & $\mathrm{H}$ & A & $\mathrm{AC}$ & $\mathrm{S}$ & $\mathrm{O}$ & $\mathrm{W}$ & $2,577.200$ & 35 & .86 & .03 & .05 \\
\hline Quercus pubescens & D & Rosidae & Fagales & Fagaceae & LP & $\mathrm{T}$ & $\mathrm{H}$ & A & $\mathrm{AC}$ & S & $\mathrm{O}$ & $\mathrm{R}$ & $2,560.056$ & 20 & .90 & .03 & \\
\hline Quercus pyrenaica & D & Rosidae & Fagales & Fagaceae & LP & $\mathrm{T}$ & $\mathrm{H}$ & A & $\mathrm{AC}$ & $\mathrm{V}$ & $\mathrm{O}$ & $\mathrm{R}$ & $2,560.056$ & 25 & .96 & & \\
\hline Quercus robur & D & Rosidae & Fagales & Fagaceae & LP & $\mathrm{T}$ & $\mathrm{H}$ & A & $\mathrm{AC}$ & S & $\mathrm{O}$ & $\mathrm{w}$ & $3,817.000$ & 35 & .78 & .02 & .20 \\
\hline Quercus rubra & D & Rosidae & Fagales & Fagaceae & LP & $\mathrm{T}$ & $\mathrm{H}$ & A & $\mathrm{AC}$ & S & $\mathrm{O}$ & E & $2,981.000$ & 40 & .47 & .09 & .10 \\
\hline Quercus suber & D & Rosidae & Fagales & Fagaceae & LP & $\mathrm{T}$ & $\mathrm{H}$ & A & $\mathrm{AC}$ & S & $\mathrm{O}$ & $\mathrm{R}$ & $2,609.000$ & 25 & .84 & .11 & -.01 \\
\hline Raphanus sativus & D & Rosidae & Brassicales & Brassicaceae & B & $\mathrm{F}$ & G & E & G & $\mathrm{S}$ & $\mathrm{O}$ & $\mathrm{W}$ & 10.750 & 1 & .55 & .03 & \\
\hline Rubus fruticosus s.l. & D & Rosidae & Rosales & Rosaceae & LP & S & $\mathrm{H}$ & E & AI & $\mathrm{v}$ & $\mathrm{O}$ & $\mathrm{W}$ & 2.490 & 3 & .31 & & \\
\hline Rumex nivalis & D & Caryophyllidae & Caryophyllales & Polygonaceae & SP & $\mathrm{F}$ & $\mathrm{D}$ & A & G & $\ldots$ & $\mathrm{O}$ & $\mathrm{R}$ & 1.000 & $\ldots$ & .58 & .21 & \\
\hline Salix caprea & D & Rosidae & Malpighiales & Salicaceae & LP & $\mathrm{T}$ & D & EA & $\mathrm{W}$ & $\mathrm{S}$ & $\mathrm{O}$ & $\mathrm{W}$ & .090 & 10 & .09 & & \\
\hline Santalum spicatum & D & & Santalales & Santalaceae & LP & $\mathrm{S}$ & $\mathrm{H}$ & $\mathrm{E}$ & AI & $\ldots$ & $\ldots$ & $\mathrm{N}$ & 234.000 & 4 & .94 & .09 & -.03 \\
\hline Saxifraga oppositifolia & D & Rosidae & Saxifragales & Saxifragaceae & SP & $\mathrm{F}$ & $\mathrm{H}$ & E & $\mathrm{W}$ & $\ldots$ & os & $\mathrm{W}$ & .089 & .3 & .82 & .15 & \\
\hline Senecio gallicus & D & Asteridae & Asterales & Asteraceae & A & $\mathrm{F}$ & $\mathrm{H}$ & E & AA & $\ldots$ & $\mathrm{O}$ & $\mathrm{R}$ & .446 & .4 & .57 & .15 & .11 \\
\hline Senecio glaucus & D & Asteridae & Asterales & Asteraceae & A & F & $\mathrm{H}$ & E & AA & $\ldots$ & $\mathrm{O}$ & W & .446 & .5 & .42 & .12 & .12 \\
\hline \multicolumn{18}{|l|}{ Senecio } \\
\hline leucanthemifolius & D & Asteridae & Asterales & Asteraceae & A & $\mathrm{F}$ & $\mathrm{H}$ & E & $\mathrm{W}$ & $\ldots$ & $\mathrm{O}$ & E & .446 & .4 & .12 & .30 & \\
\hline Senecio vernalis & D & Asteridae & Asterales & Asteraceae & A & F & $\mathrm{H}$ & $\mathrm{E}$ & AA & $\ldots$ & $\mathrm{O}$ & $\mathrm{W}$ & .446 & .5 & .05 & .04 & .12 \\
\hline Silene hifacensis & D & Caryophyllidae & Caryophyllales & Caryophyllaceae & SP & F & $\mathrm{D}$ & E & $\ldots$ & S & $\mathrm{O}$ & E & .500 & $\ldots$ & 1.00 & .58 & \\
\hline Solanum acaule & D & Asteridae & Solanales & Solanaceae & A & $\mathrm{F}$ & $\mathrm{H}$ & E & $\mathrm{G}$ & $\ldots$ & S & $\mathrm{W}$ & 2.105 & .1 & .53 & & \\
\hline Sorbus aria & D & Rosidae & Rosales & Rosaceae & LP & $\mathrm{T}$ & $\mathrm{H}$ & E & AI & $\mathrm{V}$ & $\mathrm{O}$ & $\mathrm{W}$ & 169.000 & 20 & .25 & & \\
\hline Sorbus aucuparia & D & Rosidae & Rosales & Rosaceae & LP & $\mathrm{T}$ & $\mathrm{H}$ & E & AI & $\ldots$ & $\mathrm{O}$ & W & 34.000 & 15 & .31 & .06 & -.01 \\
\hline Sorbus torminalis & D & Rosidae & Rosales & Rosaceae & LP & $\mathrm{T}$ & $\mathrm{H}$ & E & AI & $\mathrm{V}$ & $\mathrm{O}$ & $\mathrm{W}$ & 5.500 & 20 & .36 & .15 & .13 \\
\hline
\end{tabular}


Table A1 (Continued)

\begin{tabular}{|c|c|c|c|c|c|c|c|c|c|c|c|c|c|c|c|c|c|}
\hline Species & $\begin{array}{l}\text { Taxonomic } \\
\text { status }\end{array}$ & Subclass & Order & Family & Perenniality & $\begin{array}{l}\text { Growth } \\
\text { form }\end{array}$ & $\begin{array}{l}\text { Breeding } \\
\text { system }\end{array}$ & $\begin{array}{l}\text { Pollination } \\
\text { mode }\end{array}$ & $\begin{array}{c}\text { Seed } \\
\text { dispersal } \\
\text { mode }\end{array}$ & $\begin{array}{l}\text { Reproduction } \\
\text { type }\end{array}$ & $\begin{array}{l}\text { Mating } \\
\text { system }\end{array}$ & $\begin{array}{l}\text { Geographic } \\
\text { range }\end{array}$ & $\begin{array}{c}\text { Seed } \\
\text { mass } \\
\left(\mathrm{mg} \mathrm{seed}^{-1}\right)\end{array}$ & $\begin{array}{l}\text { Size } \\
(\mathrm{m})\end{array}$ & $G_{\mathrm{STm}}$ & $G_{\text {STb }}$ & $F_{\text {IS }}$ \\
\hline Tabebuia heterophylla & $\mathrm{D}$ & Asteridae & Lamiales & Bignoniaceae & LP & $\mathrm{T}$ & $\mathrm{H}$ & E & $\mathrm{W}$ & $\ldots$ & $\mathrm{O}$ & $\mathrm{W}$ & 48.414 & 25 & .58 & .36 & .00 \\
\hline Tilia cordata & $\mathrm{D}$ & Rosidae & Malvales & Malvaceae & LP & $\mathrm{T}$ & $\mathrm{H}$ & E & W & $\mathrm{s}$ & $\mathrm{O}$ & $\mathrm{W}$ & 46.300 & 23 & .57 & & \\
\hline Tilia platyphyllos & $\mathrm{D}$ & Rosidae & Malvales & Malvaceae & LP & $\mathrm{T}$ & $\mathrm{H}$ & E & W & $\mathrm{S}$ & $\mathrm{O}$ & $\mathrm{W}$ & 87.000 & 30 & .41 & & \\
\hline Trillium grandiflorum & M & Liliidae & Liliales & Melanthiaceae & SP & F & $\mathrm{H}$ & $\mathrm{E}$ & AI & $\ldots$ & $\mathrm{O}$ & $\mathrm{W}$ & 10.700 & .45 & .95 & .35 & .29 \\
\hline Ulmus glabra & $\mathrm{D}$ & Rosidae & Rosales & Ulmaceae & LP & $\mathrm{T}$ & $\mathrm{H}$ & A & $\mathrm{W}$ & $\mathrm{v}$ & $\mathrm{O}$ & $\mathrm{W}$ & 14.100 & 19.9 & .61 & & \\
\hline Ulmus minor & D & Rosidae & Rosales & Ulmaceae & LP & $\mathrm{T}$ & $\mathrm{H}$ & A & W & $\mathrm{V}$ & $\mathrm{O}$ & $\mathrm{W}$ & 20.897 & 25 & .47 & & \\
\hline Vitis vinifera & $\mathrm{D}$ & Rosidae & Vitales & Vitaceae & LP & $\mathrm{V}$ & $\mathrm{D}$ & A & AI & $\mathrm{v}$ & $\mathrm{O}$ & $\mathrm{W}$ & 36.300 & 35 & .19 & .14 & .34 \\
\hline Vouacapoua americana & $\mathrm{D}$ & Rosidae & Fabales & Fabaceae & LP & $\mathrm{T}$ & $\mathrm{H}$ & E & AA & S & OS & E & $6,260.000$ & 40 & .89 & .08 & .08 \\
\hline Note: $\quad$ Ellipses indic & te no data. & & & & & & & & & & & & & & & & \\
\hline
\end{tabular}




\title{
Appendix B from J. Duminil et al., "Can Population Genetic Structure Be Predicted from Life-History Traits?"
}

\author{
(Am. Nat., vol. 169, no. 5, p. 662)
}

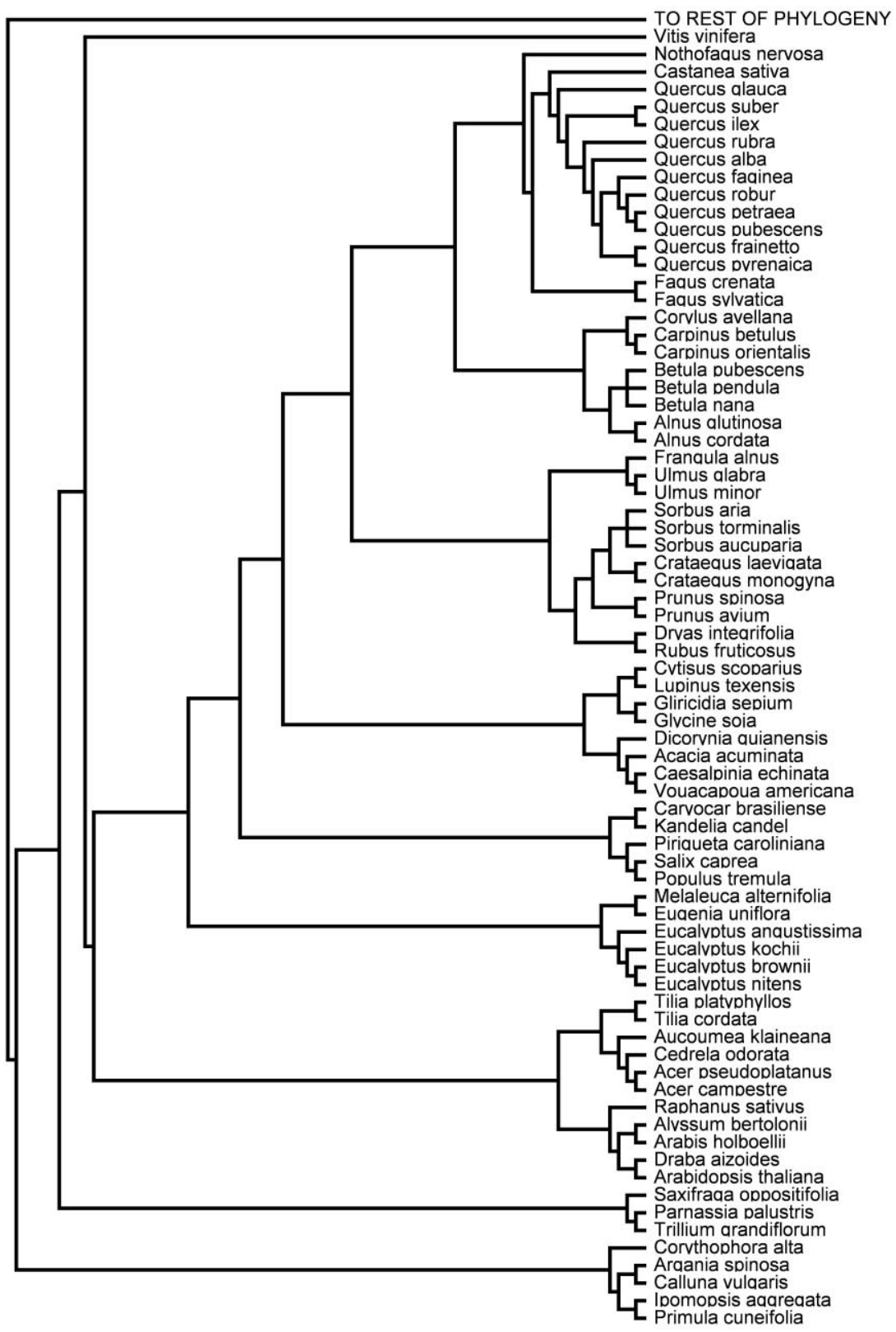

Figure B1: Phylogenetic tree used in the comparative analyses. 
App. B from J. Duminil et al., "Predicting Population Genetic Structure"

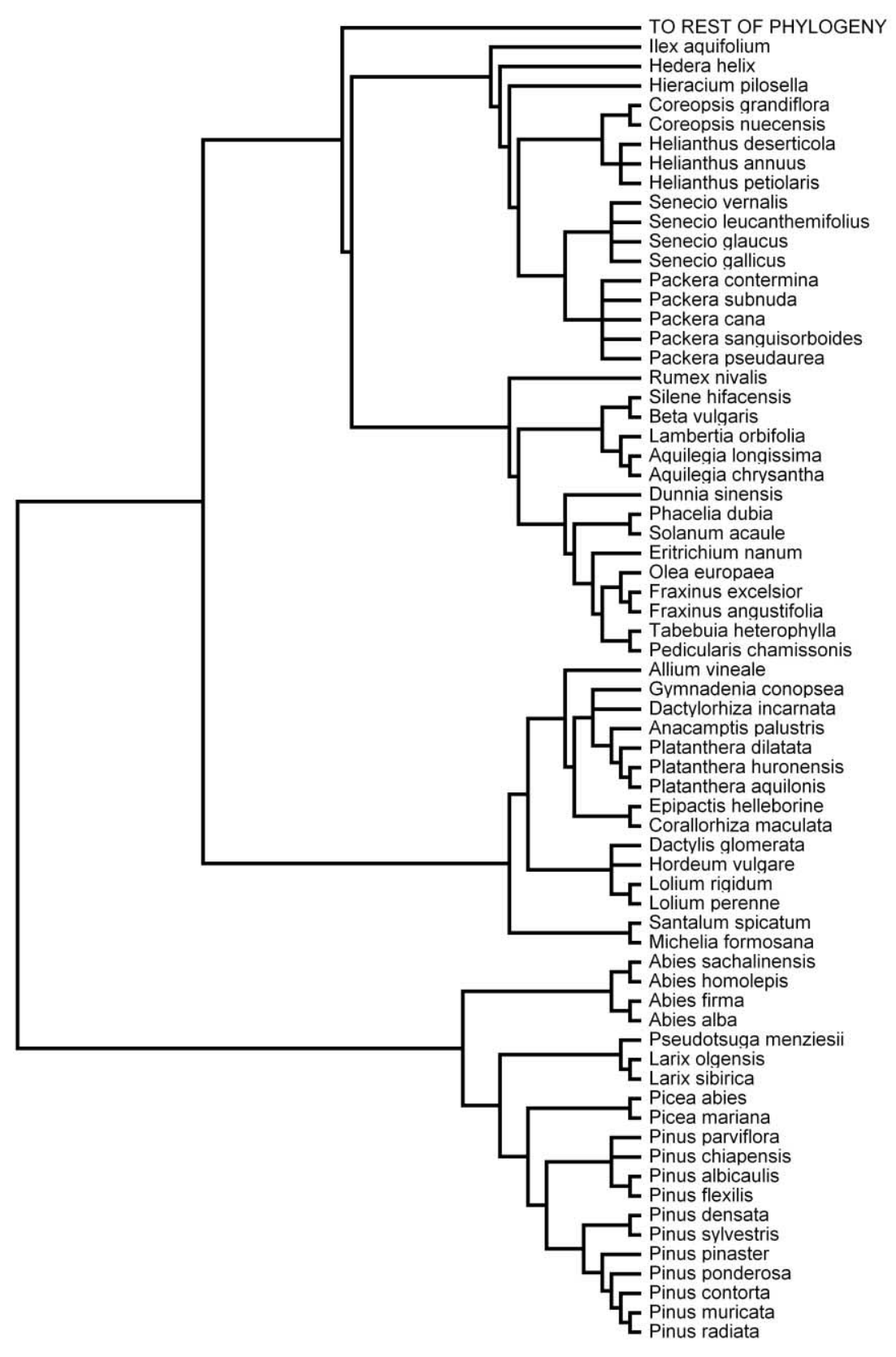

Figure B1 (Continued) 


\section{Appendix C from J. Duminil et al., "Can Population Genetic Structure Be Predicted from Life-History Traits?"}

(Am. Nat., vol. 169, no. 5, p. 662)

Table C1

Garland's test of the effect of branch length

\begin{tabular}{lccl}
\hline Parameter & Correlation & $N$ & $P$ \\
\hline$G_{\text {STb }}$ & .05 & 112 & .41 \\
$G_{\text {STm }}$ & -.07 & 141 & .60 \\
Plant size & .09 & 126 & .31 \\
Seed weight & -.05 & 126 & .58 \\
$F_{\text {IS }}$ & .13 & 69 & .29 \\
\hline
\end{tabular}

Note: For each continuous variable investigated, the correlation between the absolute values of the standardized contrasts and the standard deviations of those contrasts is provided and tested against 0 (after Garland et al. 1992). Results were obtained with the PDAP:PDTree package enclosed in the MESQUITE software (ver. 1.02; http://www.mesquiteproject.org/ mesquite/mesquite.html). 


\title{
Appendix D from J. Duminil et al., "Can Population Genetic Structure Be Predicted from Life-History Traits?"
}

\author{
(Am. Nat., vol. 169, no. 5, p. 662)
}

Table D1

Comparison of genetic structure across traits categories

\begin{tabular}{|c|c|c|c|c|}
\hline Variable & $N$ & $G_{\mathrm{STb}}$ mean & $N$ & $G_{\mathrm{STm}}$ mean \\
\hline \multicolumn{5}{|l|}{ Taxonomic status: } \\
\hline Gymnosperms & 31 & $.12(.11)$ & 20 & $.76(.16)$ \\
\hline Eumagnoliid & 13 & $.31(.14)$ & 15 & $.62(.24)$ \\
\hline Eudicots & 72 & $.16(.15)$ & 106 & $.63(.24)$ \\
\hline \multicolumn{5}{|l|}{ Growth form: } \\
\hline Herbaceous & 40 & $.27(.21)$ & 51 & $.62(.26)$ \\
\hline Shrub & 5 & $.20(.16)$ & 14 & $.59(.26)$ \\
\hline Tree & 73 & $.13(.13)$ & 76 & $.68(.24)$ \\
\hline \multicolumn{5}{|l|}{ Perenniality: } \\
\hline Annuals/biennials & 20 & $.27(.25)$ & 18 & $.58(.23)$ \\
\hline Short-lived perennials & 20 & $.28(.17)$ & 33 & $.64(.28)$ \\
\hline Long-lived perennials & 76 & $.14(.13)$ & 90 & $.67(.25)$ \\
\hline \multicolumn{5}{|l|}{ Seed dispersal mode: } \\
\hline Wind & 53 & $.18(.19)$ & 58 & $.64(.24)$ \\
\hline Animal ingested & 12 & $.26(.18)$ & 22 & $.53(.25)$ \\
\hline Animal attached & 12 & $.25(.16)$ & 14 & $.58(.30)$ \\
\hline Animal cached & 15 & $.06(.04)$ & 19 & $.75(.21)$ \\
\hline Gravity & 17 & $.20(.14)$ & 21 & $.71(.25)$ \\
\hline \multicolumn{5}{|l|}{ Pollination mode: } \\
\hline Anemophilous & 54 & $.12(.11)$ & 54 & $.73(.24)$ \\
\hline Zoophilous & 53 & $.24(.20)$ & 77 & $.60(.25)$ \\
\hline \multicolumn{5}{|l|}{ Mating system: } \\
\hline Outcrossed & 93 & $.16(.14)$ & 114 & $.65(.25)$ \\
\hline Mixed & 12 & $.14(.12)$ & 16 & $.73(.21)$ \\
\hline Selfed & 6 & $.56(.24)$ & 6 & $.72(.19)$ \\
\hline \multicolumn{5}{|l|}{ Breeding system: } \\
\hline Monoecious & 105 & $.19(.18)$ & 129 & $.66(.25)$ \\
\hline Dioecious/gynodioecious & 5 & $.19(.23)$ & 12 & $.58(.33)$ \\
\hline \multicolumn{5}{|l|}{ Reproduction type: } \\
\hline Sexual and vegetative & 21 & $.19(.14)$ & 70 & $.58(.26)$ \\
\hline Only sexual & 82 & $.18(.18)$ & 71 & $.72(.22)$ \\
\hline \multicolumn{5}{|l|}{ Geographic range: } \\
\hline Endemic & 19 & $.18(.16)$ & 21 & $.63(.27)$ \\
\hline Narrow & 15 & $.18(.18)$ & 16 & $.80(.18)$ \\
\hline Regional & 29 & $.19(.15)$ & 32 & $.70(.25)$ \\
\hline Widespread & 53 & $.18(.19)$ & 72 & $.60(.25)$ \\
\hline
\end{tabular}




\section{Appendix E from J. Duminil et al., "Can Population Genetic Structure} Be Predicted from Life-History Traits?"

(Am. Nat., vol. 169, no. 5, p. 662)

Plant size (Log transformed)

Perenniality

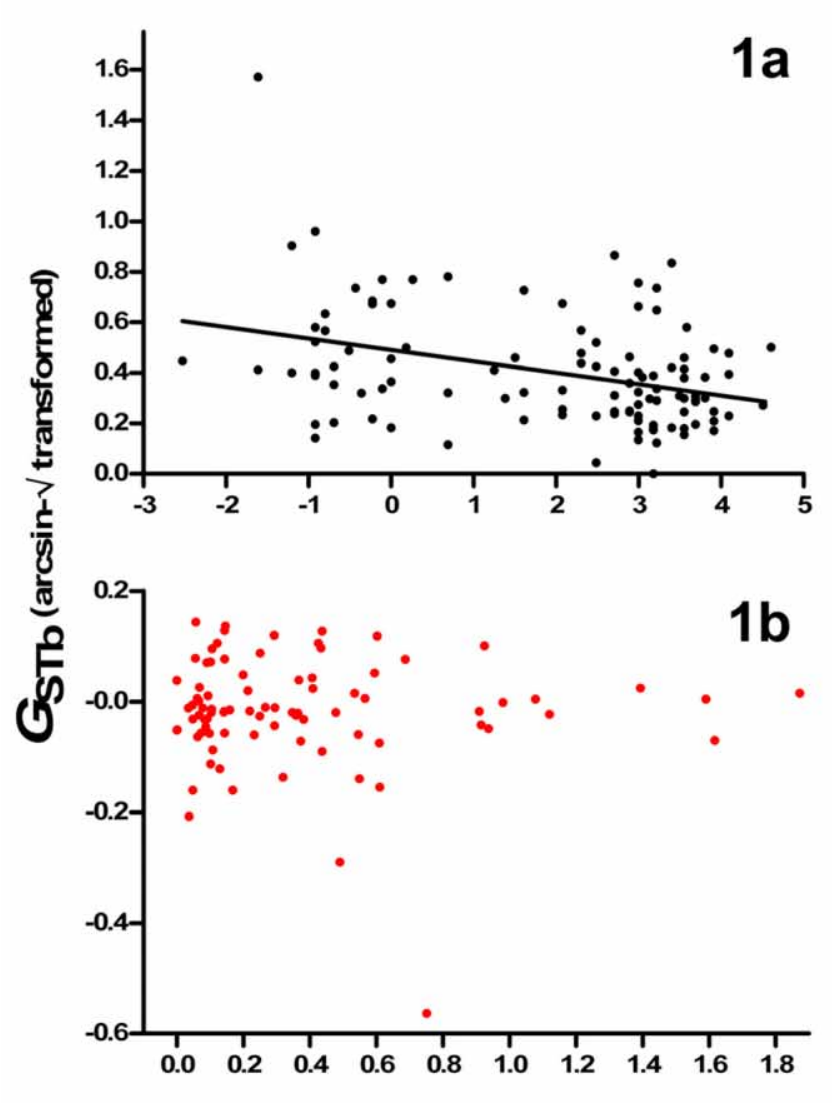

$2 a$

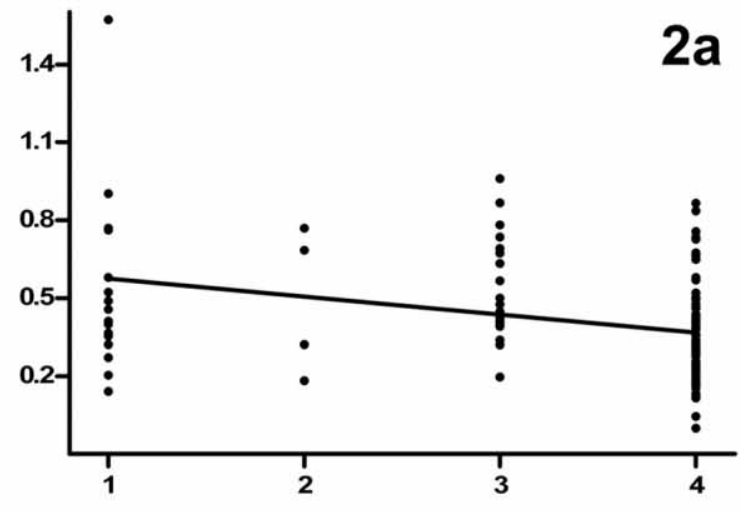

2b
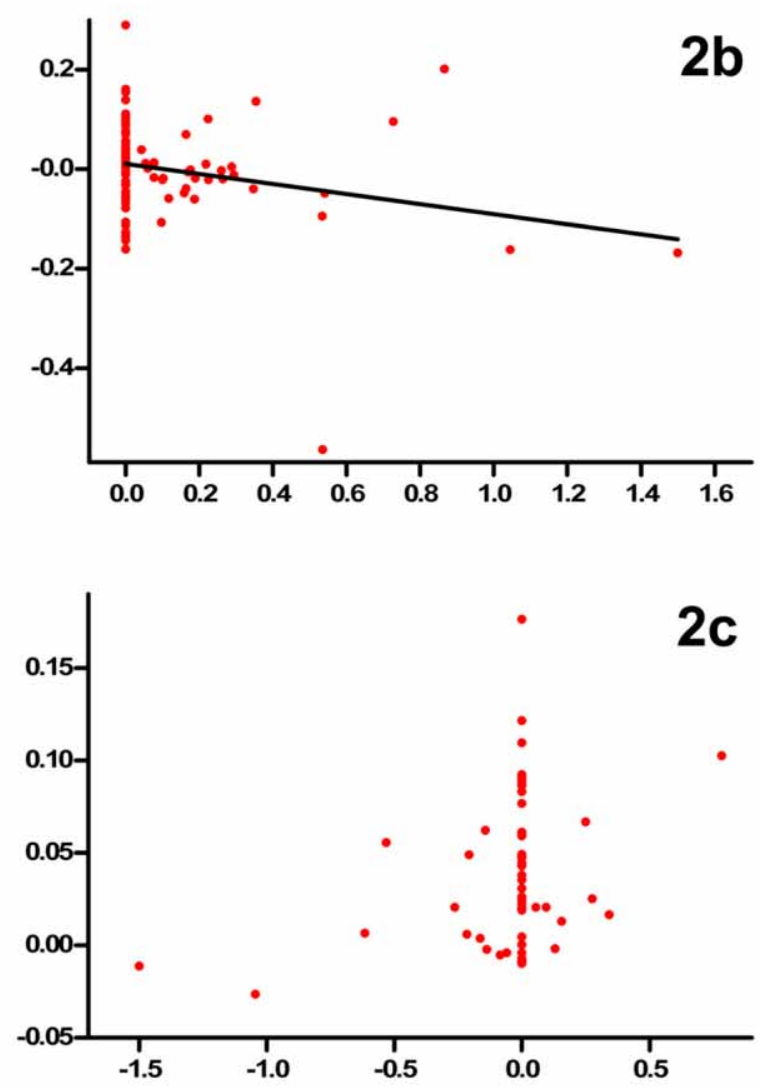
App. E from J. Duminil et al., "Predicting Population Genetic Structure"

Figure E1: Illustration of the necessity to control for phylogenetic relationships and confounding covariates in cross-species analyses of genetic structure. $l a$, Plot of $G_{\mathrm{Sть}}$ on plant size (TIPs analysis). $l b$, Plot of the contrasts of $G_{\mathrm{STb}}$ on the contrasts of plant size (PICs analysis). The major axis regression line is shown when significant. The relation initially detected is no longer significant when controlling for phylogeny. $2 a$, Plot of $G_{\mathrm{STb}}$ on perenniality (TIPs analysis). $2 b$, Plot of the contrasts of $G_{\mathrm{STb}}$ on the contrasts of the perenniality (PICs analysis). $2 c$, Plot of the contrasts of $G_{\mathrm{STb}}$ on the contrasts of the perenniality (PICs analysis) when $F_{\mathrm{IS}}$ is used as a covariate. The major axis regression line is shown when significant. The relation is still significant when controlling for phylogeny but not when including $F_{\mathrm{IS}}$ as a covariate. 